\title{
Durability Performance of SCC and SCGC Containing Recycled Concrete Aggregates: A Comparative Study
}

\author{
Tehmina Ayub *(D), Wajeeha Mahmood (D) and Asad-ur-Rehman Khan (D) \\ Department of Civil Engineering, NED University of Engineering and Technology, Karachi 75270, Pakistan; \\ wajeehamahmood@neduet.edu.pk (W.M.); asadkhan@neduet.edu.pk (A.-u.-R.K.) \\ * Correspondence: tehmina@neduet.edu.pk
}

check for updates

Citation: Ayub, T.; Mahmood, W.; Khan, A.-u.-R. Durability Performance of SCC and SCGC Containing Recycled Concrete Aggregates: A Comparative Study. Sustainability 2021, 13, 8621. https:// doi.org/10.3390/su13158621

Academic Editors: Ruoyu Jin, Yidong $\mathrm{Xu}$, Libo Yan and Zhenhua Duan

Received: 24 June 2021

Accepted: 28 July 2021

Published: 2 August 2021

Publisher's Note: MDPI stays neutral with regard to jurisdictional claims in published maps and institutional affiliations.

Copyright: (c) 2021 by the authors. Licensee MDPI, Basel, Switzerland. This article is an open access article distributed under the terms and conditions of the Creative Commons Attribution (CC BY) license (https:// creativecommons.org/licenses/by/ $4.0 /)$.

\begin{abstract}
This study assesses the behaviour of self-compacting geopolymer concrete (SCGC) with and without recycled concrete aggregates (RCA) by studying the rheological, mechanical and durability properties and comparison with self-compacting concrete (SCC). The idea of using RCA in geopolymer is to attain sustainable development goals, i.e., with less carbon footprint and the use of waste materials such as fly ash and RCA. Two types of concretes were prepared, namely "self-compacting concrete (SCC)" and "self-compacting geopolymer concrete (SCGC)". Using each concrete type, two design mixes were prepared. The first mix contained $100 \%$ natural coarse aggregates (NCA), whereas, in the second mix, 30\% NCA were replaced with RCA. The result of rheological properties indicated that the viscosity, passing ability, and segregation results of SCC and SCGC mixes were higher when NCA was partially replaced with RCA. Results of mechanical properties indicated that the increase in the compressive strength of the control mix of SCC (denoted as SCC-0) and SCGC mix (denoted as SCGC-0) at 28 days was $38.3 \%$ and $33.1 \%$ higher than those containing $30 \%$ RCA (denoted as SCC-30 and SCGC-30), respectively. The percentage increase in the compressive strength of SCC- 0 and SCC-30 mixes was $20.24 \%$ and $13.45 \%$ higher compared to SCGC-0 and SCGC-30 mixes. The increase in the split tensile strength of SCC-0 and SCC-30 mixes was $9 \%$ and $21.74 \%$ higher than SCGC-0 and SCGC-30 mixes. The split tensile strength of control mixes SCC- 0 and SCGC-0 is $47.73 \%$ and 55\% higher than SCC-30 and SCGC-30 at 28 days, respectively. Durability performance of SCC and SCGC mixes was investigated by performing hydraulic permeability, accelerated carbonation, half-cell potential and pull-out tests at 28, 90, 180, 365, and 720 days, and were found inferior for SCGC mixes. The water penetration depth of SCGC-0 and SCGC-30 mixes was $5.71 \%$ to $16.1 \%$ and $10 \%$ to $18.6 \%$ higher than SCC- 0 and SCC-30 mixes at 28 to 720 days. The carbonation depth in SCGC- 0 and SCGC-30 mixes was $8.11 \%$ to $20.83 \%$ and $7.89 \%$ to $13.73 \%$ higher than SCC- 0 and SCC-30 mixes at 28 to 720 days. The half-cell potential difference results for SCGC-0 and SCGC-30 mixes were $27.5 \%$ to $50 \%$ and $8.3 \%$ to $16.41 \%$ higher than SCC- 0 and SCC-30 mixes at 28 to 720 days. The pull-out strength of SCC-0 and SCC-30 mixes was $11.36 \%$ to $29.5 \%$ and $8.3 \%$ to $38.97 \%$ higher than SCGC-0 and SCGC-30 mixes at 28 to 720 days, respectively. Overall, the mechanical and durability properties of SCC mixes were better than SCGC at the same exposure period.
\end{abstract}

Keywords: sustainability; mechanical properties; durability properties; natural coarse aggregate (NCA); recycled concrete aggregates (RCA); self-compacting concrete (SCC); self-compacting geopolymer concrete (SCGC)

\section{Introduction}

Self-compacting geopolymer concrete (SCGC) is comparatively a fresh notion and can be regarded as an innovative development in the area of concrete technology. The revolutionary properties of SCGC include that it does not require vibration for its compaction and placing (as almost all concretes properties essentially rely on being fully compacted) and is produced the without using ordinary Portland cement (OPC) [1]. Geopolymer concrete typically replaces cement-based binder with an alternative binder. The knowledge of the 
the behaviour of both cement and olgeopolymer based self-compacting concrete (SCC and SCGC) using natural coarse aggregates (NCA) is well-established [1-6]; however, limited literature exists describing the durability-related behaviour of both concretes, i.e., SCC and SCGC using recycled concrete aggregates (RCA).

Reddy et al. [2] reported the results of mechanical and durability properties of SCC of grades M20 (mix with $20 \mathrm{MPa}$ compressive strength), M40 (mix with 40MPa compressive strength), and M60 (mix with $60 \mathrm{MPa}$ compressive strength), incorporating 0\%, 25\%, 50\%, and $100 \%$ RCA. They [2] reported the results of compressive strength, acid resistance, and water sorption and suggested that the optimum NCA content that can be replaced with RCA without any detrimental effect on the concrete is $25 \%$ for medium concrete strength. In another study using the same mix design and concrete strengths as used in [2], Reddy et al. [3] reported the contribution of fly ash and silica fume by putting a check on cement content effect at 28, 56 and 90 days. They [4] estimated the service life period from previous models for each SCC mix of grades M20, M40, and M60 based on the sorptivity test to explore durability and determined that the NCA can be replaced up to $25 \%$ for medium-strength concrete. Similarly, $20 \%$ of NCA can be replaced for high strength concrete with not more than $10 \%$ performance lenience compared to natural coarse aggregate concretes [4]. Modani and Mohitkar [5] examined the effect of using RCA in SCC from $0 \%$ to $100 \%$ with $20 \%$ variation to replace natural aggregates on the strength and few aspects of durability including permeability, resistance to acid attack, chloride penetration, and alkalinity. The results of the investigation [5] showed effective use of RCA in SCC without any noteworthy decrease in strength and durability. Kapoor et al. [6] assessed the durability properties of self-compacting concrete (SCC) prepared from RCA as $0 \%, 50 \%$ and $100 \%$ replacement of NCA kept at curing periods of 28,56 , and 120 days. The durability properties investigated by Kapoor et al. [6] were Rapid Chloride Penetrability Test (RCPT), Initial Surface Absorption Test (ISAT), Water Penetration Test and Capillary Suction Test (CST). In SCC, 10\% weight of Portland cement (PC) was replaced with Silica Fume (SF) or Metakaolin (MK). This replacement was also suggested by Ayub et al. [7]. In a study by Kapoor et al. [6], it was concluded that the use of RCA reduces 28-days compressive strength but the addition of MK (compared to SF) was beneficial in regaining the actual compressive strength. Moreover, the use of both SF, as well as MK, significantly reduced penetration of chloride ion at all curing ages in SCC made from NCA and at all replacement levels of NCA with RCA; however, MK controlled initial surface absorption as compared to SF. Initial surface absorption and water penetration depth were found to be increasing in control concrete with an increase in the replacement percentage of RCA along with the curing period. Apart from durability, several researchers [8,9] reported hardened concrete properties. Tang et al. [8] examined the mechanical and fracture properties of SCC containing 0, 25\%, 50\%, 75\%, and 100\% coarse RCA. According to them [8], there is little or no reduction in strength (compressive, tensile, and modulus of elasticity), workability, or fracture properties. However, the modulus of elasticity for $100 \%$ RCA SCC was found to be notably reduced as compared to control SCC due to possible issues with the brittleness of SCCs. Satish et al. [9] observed the desired flowability of SCC in terms of flowability index at various replacement percentage levels of NCA with RCA using High Range Water reducing agent (HRWR) with and without Viscosity modifying agent (VMA). According to authors [9], the compressive strength was significantly reduced compared to control SCC beyond $20 \%$ replacement of NCA with RCA.

Geopolymer concrete is gaining significant attention in the construction industry. In geopolymer concrete, an alternative binder containing activated fly ash is used as a replacement for cement. The alkaline solution of sodium silicate $\left(\mathrm{Na}_{2} \mathrm{SiO}_{3}\right)$ and sodium hydroxide $(\mathrm{NaOH})$ is used to activate the alternative binder in geopolymer concrete. Manufacturing of Portland cement contributes an equivalent amount of carbon dioxide $\left(\mathrm{CO}_{2}\right)$ to the atmosphere [10]. Therefore, the use of fly ash is common worldwide because of its availability, composition, and low loss on ignition. Geopolymer concrete does not contain cement and the bond between aggregates is created by using industrial by-products like fly ash and 
other alumino-silicates. Memon et al. [11] reported that the fluidity of SCGC is dependent on the quantity of sodium hydroxide $(\mathrm{NaOH})$ and on increasing the proportion of sodium hydroxide, the cohesiveness of SCGC mix increases. Cihangir et al. [12] recommend that for alkali-activated slag (AAS) mixes, $\mathrm{SiO}_{2}$ and $\mathrm{Na}_{2} \mathrm{O}$, present as solid content in activator, are responsible for determining the quantity of binders. The modulus ratio $\left(\mathrm{SiO}_{2} / \mathrm{Na}_{2} \mathrm{O}\right)$ of $\mathrm{Na}_{2} \mathrm{SiO}_{3}$ was set at a fixed value along with $\mathrm{NaOH}$ to achieve the required workability. The changes in the strength of geopolymer concrete with self-compacting properties were first introduced in 2011 and named "Self-Compacting Geopolymer Concrete (SCGC) to overcome the issue of compaction in geopolymer concrete [11]. The compressive and tensile strength of fly ash based geopolymer concrete is comparable to ordinary Portland cement concrete at up to $65 \mathrm{MPa}$ and $5.73 \mathrm{MPa}$ [13]. If recycled coarse aggregates (RCA) are added to SCGC, it can result in around a 60 percent reduction in the accumulation of construction and demolition waste along with a 50 percent reduction in depletion of natural mineral resources per cubic meter of concrete produced. Despite the compositional variability of RCA, when RCA is added to geopolymer concrete and the large variation in compressive strength has not been reported, which is consistent with results for non-RCA batch [14]. Furthermore, the addition of self-compaction properties makes this concrete more attractive to the construction industry stakeholders (specifically the precast industry).

To date, limited literature is available on SCGC. Using RCA, Naganur et al. [15] conducted the study on SCGC with an alkaline activator ratio (AAR) of 4 and different alkaline activator to cementitious binder ratios as $0.4,0.45,0.5$ and 0.55 , respectively. They [15] suggested that the compressive strength test be carried out for 3, 7, 28 and 91 days. A higher value of compressive strength was achieved at 91 days and the ratio of coarse to fine aggregate used was 60:40, which indicates that an increment in the amount of coarse aggregates would increase the hardness and ultimately the compressive strength of concrete. In addition, the use of crushed granite with $6 \%$ superplasticizer also led to an increase in compressive strength. Furthermore, it is also observed that Ground Granulated Blastfurnace Slag (GGBS) gives a higher compressive strength relative to fly ash. Waste glass powder increases the compressive strength by $30 \mathrm{MPa}$, and also serves as an outstanding contender for silica fume. An increase in the $\mathrm{NaOH}$ molarity leads to an increase in the compressive strength, additionally. Further, it has been stated by Naganur et al. [15] that the process of geopolymerization affects the tensile strength of SCGC. The lowest split tensile strength was found at ambient temperature due to the slow rate of geopolymerization. The temperature and mix variables not only affect the tensile strength, which was found to be the same as that of SCGC, but also influence compressive strength [11]. The durability properties of SCGC with and without recycled aggregate have not been studied yet, but from several pieces of research [16-19] the durability properties of geo-polymer concrete with and without RCA can be inferred. These studies [16-19] are used as a reference in the present study for the durability properties of SCGC. Recently, geopolymer recycled aggregate concrete is studied in detail from the perspective of experiments to empirical models as well [20]. Recently, geopolymer recycled aggregate concrete is studied in detail from the perspective of experiments to empirical models as well [20].

From the literature review, it was found that there is no work reported relating to the mechanical and durability-related investigation of SCGC containing recycled concrete aggregates. Salihi and Younis [21] observed the effect of $\mathrm{Na}_{2} \mathrm{SiO}_{3} / \mathrm{NaOH}$ and the molarity of $\mathrm{NaOH}$ on the rheological behaviour of SCGC, and the literature review further identifies that the replacement percentage of $30 \%$ can safely be adopted to study the behaviour of SCC and SCGC using RCA. The behaviour of these two concretes was also compared, which indicates that the replacement of up to $30 \%$ natural aggregate fraction with recycled aggregate is feasible, as only $10 \%$ to $20 \%$ difference in mechanical and durability test results were observed. SCC is found to be more resistant to penetration of water and carbon dioxide as compared to SCGC. Furthermore, SCC has higher bond strength, compression, and split tensile strength as compared to SCGC. Thus, this research is an attempt towards the development of sustainable concrete for the construction industry benefiting from the 
geopolymer technology and use of waste materials, i.e., RCA and fly ash in SCGC. The recycled concrete aggregates were acquired from local construction and demolition sites that would otherwise be disposed of in landfills. Thus, this research is a step towards the development of the construction industry by providing useful information for the practical use of recycled aggregate in concrete production.

\section{Experimental Program}

Based on a study [22] conducted at the Department of Civil Engineering, NED University of Engineering \& Technology, it was found that the compression test results of replacement percentages 0 and $30 \%$ differ no more than $20 \%$ to $30 \%$ from values obtained for ordinary Portland cement (OPC) concrete. Therefore, this range of replacement percentages was adopted to assess the effect of RCA on the behaviour of SCC and SCGC mixes, while the other replacement percentages were excluded from this study. In both mix designs (i.e., SCC and SCGC), Class F fly ash was used as a binder (refer to Figure 1). The physical and chemical characteristics of fly ash are given in Table 1.

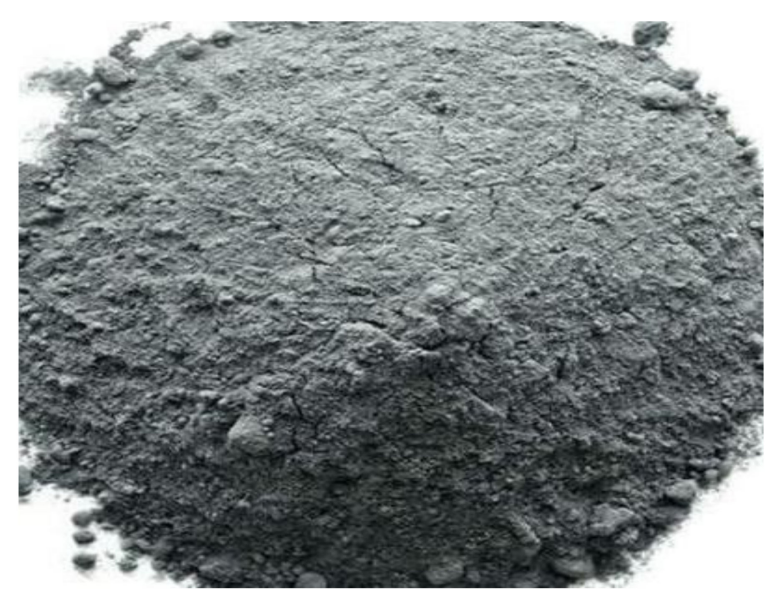

Figure 1. Fly ash (Class F).

Table 1. Physical and chemical composition of fly ash.

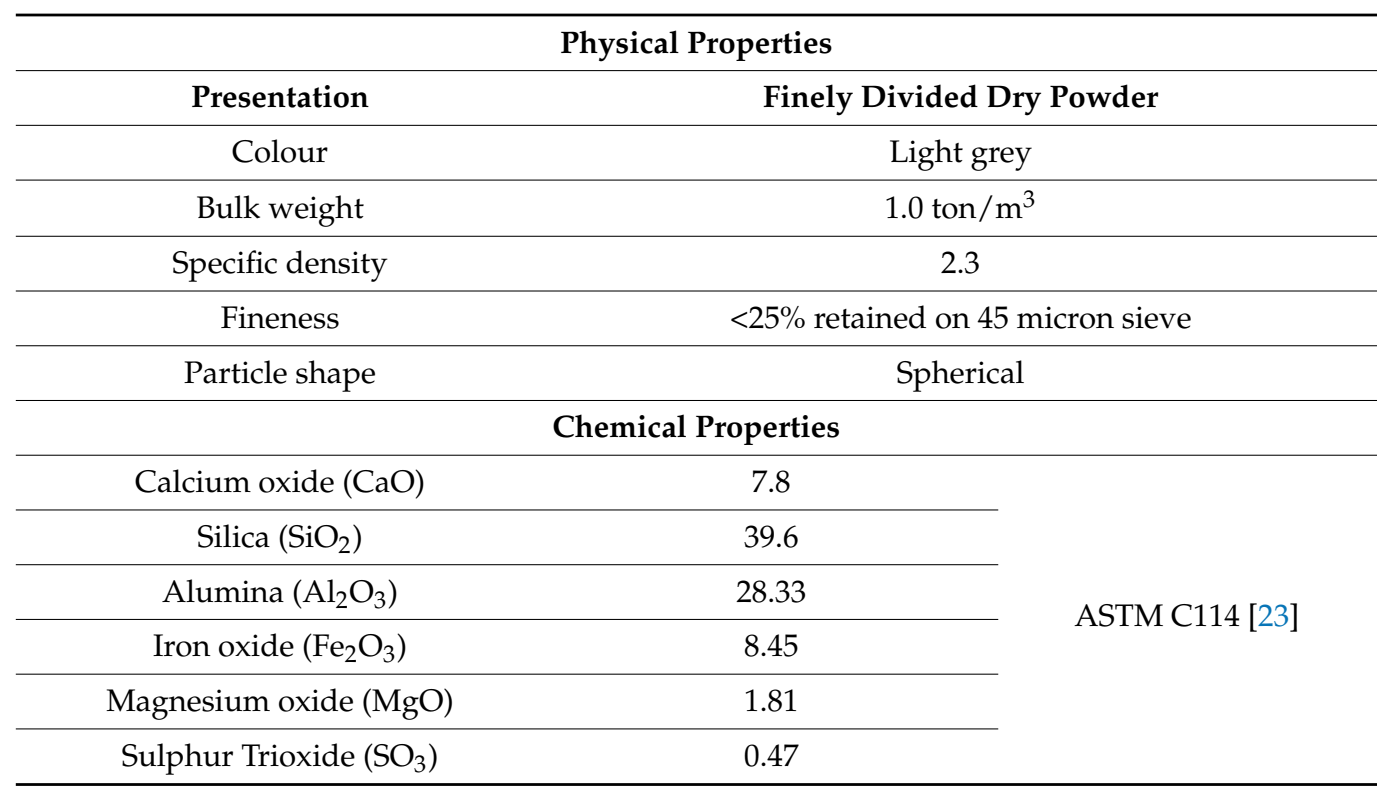


Table 1. Cont.

\begin{tabular}{cc}
\hline & Physical Properties \\
\hline Chloride $(\mathrm{Cl})$ & 0.031 \\
\hline Alkali Eq. & 0.89 \\
\hline Water-soluble phosphate $\left(\mathrm{P}_{2} \mathrm{O}_{5}\right)$ & 0.52 \\
\hline Manganese oxide $(\mathrm{MnO})$ & 0.38 \\
\hline Phosphorus oxide $\left(\mathrm{P}_{2} \mathrm{O}_{5}\right)$ & 1.16 \\
\hline Potassium oxide $\left(\mathrm{K}_{2} \mathrm{O}\right)$ & 1.68 \\
\hline Sodium oxide $\left(\mathrm{Na}_{2} \mathrm{O}\right)$ & 1.44 \\
\hline Titanium oxide $\left(\mathrm{TiO}_{2}\right)$ & 1.13 \\
\hline Free CaO & 3.2 \\
\hline Loss on Ignition $(\mathrm{LOI})$ & 3.1 \\
\hline
\end{tabular}

Fly ash is a fine powder obtained as a final waste product after incineration of the pulverized coal in the power stations [11]. As shown in Figure 1 and Table 1, Class F fly ash was used, which mainly consisted of alumina and silica and has a higher loss on ignition (LOI) of 3.1.

For SCC and SCGC mixes, the target compressive strength was set at $28 \mathrm{MPa}$ and it was ensured that the same coarse aggregate sizes of $10 \mathrm{~mm}$ and $12 \mathrm{~mm}$ for natural and recycled were used. Recycled coarse aggregates were obtained from previously tested beams in the Material Testing Laboratory, Department of Civil Engineering, NED University of Engineering and Technology. The coarse aggregates were used in the two ratios of NCA: RCA as 100:0 and 70:30. Hence, the conclusive dry mix ratio is fly ash:Fine aggregate:Coarse aggregate $=1: 2.125: 2.375$. Due to the higher water absorption of RCA, the recycled aggregates were soaked in water for $24 \mathrm{~h}$ and then surface dried before use in the preparation of the concrete batch.

Natural siliceous sand was used as a fine aggregate with grain size ranging from 0.15 to $5 \mathrm{~mm}$ and specific gravity, bulk unit weight, and fineness modulus of $2.67,1686 \mathrm{~kg} / \mathrm{m}^{3}$, and 2.76, respectively. The grading curve of fine aggregate came under the area of gradation zone-2, as shown in [24].

The experimental test program was based on mechanical and durability properties. The mechanical testing was divided into two categories: fresh state properties and hardened state properties. In fresh state properties, SCC and SCGC are characterised by the flowing ability, passing ability, filling ability, and segregation resistance. The hardened state properties are characterised by compressive and tensile strengths depending on the mix design of concrete. The details of durability testing are illustrated in the forthcoming sections.

\subsection{Experimental Design for Self-Compacting Concrete (SCC)}

Locally available ordinary Portland cement with a fineness of $320 \mathrm{~m}^{2} / \mathrm{kg}$ was used to prepare SCC mixes. Viscosity modifying agent (VMA) was also used to produce selfcompacting behaviour. The recycled concrete aggregates were obtained from the same source as used in the design mix of Ordinary Portland cement concrete [22]. The mix design was adopted from [4] with slight modification. The mix design mixtures with detailed components are shown in Table 2.

In each mix, 30\% RCA was used for high strength SCC. This replacement percentage was based on the recommendations of Reddy et al. [3] and a previous study [22] conducted in the Department of Civil Engineering over the last 2 years.

The mix quantities for the control mix (SCC-0) were adopted from one of the previous studies undertaken by Reddy et al. [4]. The mix proportion was modified after trials to achieve adequate workability. The amount of all the mixing material components was kept constant for every cubic meter of concrete except the quantity of superplasticizer (SP) 
for every batch either with or without recycled aggregate. For concrete with RCA (i.e., SCC-30), the amount of superplasticizer was increased due to the higher water absorption of recycled aggregates. The SCC mixes were prepared in the concrete laboratory of the Department of Civil Engineering using a pan mixer of 100 litres' capacity according to the instruction given in European Guidelines for Self-Compacting Concrete Specification, Production and Use (EFNARC) [25].

Table 2. Details of SCC mixes per $\mathrm{m}^{3}$ concrete.

\begin{tabular}{|c|c|c|c|c|c|c|c|c|c|}
\hline \multirow[b]{2}{*}{$\begin{array}{l}\text { Mix } \\
\text { Type }\end{array}$} & \multirow[b]{2}{*}{$\begin{array}{c}\text { Cement } \\
\text { (kg) }\end{array}$} & \multirow[b]{2}{*}{$\begin{array}{c}\text { Fly Ash } \\
\text { (kg) }\end{array}$} & \multicolumn{2}{|c|}{ Coarse Aggregate, kg } & \multirow{2}{*}{$\begin{array}{c}\text { Fine } \\
\text { Aggregate, } \\
\text { (kg) }\end{array}$} & \multirow[b]{2}{*}{ Water (kg) } & \multirow{2}{*}{$\begin{array}{c}\text { w/b Ratio } \\
\text { =Water }(\mathrm{kg}) / \\
\text { (Cement + Fly } \\
\text { Ash) (kg) }\end{array}$} & \multirow{2}{*}{$\begin{array}{c}\text { SP } \\
\text { Dosage, } \\
(\mathrm{kg})\end{array}$} & \multirow[b]{2}{*}{$\begin{array}{c}\text { Dose }(\%)=\text { Dose } \\
(\mathrm{kg}) /(\mathrm{Cement}+ \\
\text { FA) }(\mathrm{kg}) \times 100\end{array}$} \\
\hline & & & Normal & Recycled & & & & & \\
\hline SCC-0 & 290 & 155 & 812 & 0 & 957 & 185 & \multirow{2}{*}{0.48} & \multirow{2}{*}{6.675} & \multirow{2}{*}{$1.5 \%$} \\
\hline SCC -30 & 290 & 155 & 568 & 244 & 957 & 185 & & & \\
\hline
\end{tabular}

\subsection{Experimental Design for Self-Compacting Geopolymer Concrete (SCGC)}

Alkaline Activator Solution (AAS)

Alkaline solution plays an important role in geopolymerization, which is a process of heating sodium hydroxide $(\mathrm{NaOH})$ and sodium silicate $\left(\mathrm{Na}_{2} \mathrm{SiO}_{3}\right)$. The alkaline solution used in this study was a combination of $\mathrm{NaOH}$ and $\mathrm{Na}_{2} \mathrm{SiO}_{3}$. The reason behind the selection of sodium-based solution was its lower cost. $\mathrm{Na}_{2} \mathrm{SiO}_{3}$ was used in solution form. The water to binder $(\mathrm{w} / \mathrm{b})$ ratio was taken equal to water to geopolymer (W/GP) solid. In Engineered geopolymer Composites (EGC), 8.0 Molar (8.0 M) solution of $\mathrm{NaOH}$ was used, which is equal to $52 \mathrm{~kg} / \mathrm{m}^{3}$ by volume in the mix, recommended by the research community to attain pseudo-strain-hardening (PSH) response [26]. A laboratory-grade pallet of $\mathrm{NaOH}$ was mixed in distilled water to obtain the required concentration of $\mathrm{NaOH}$ solution. Sodium silicate $\left(\mathrm{Na}_{2} \mathrm{SiO}_{3}\right)$ solution with $14.7 \% \mathrm{Na}_{2} \mathrm{O}, 32.75 \% \mathrm{SiO}_{2}$, and $52.52 \%$ $\mathrm{H}_{2} \mathrm{O}$ by weight was used in the mix design, which is equal to $143 \mathrm{~kg} / \mathrm{m}^{3}$ by volume in the mix. The $\mathrm{Na}_{2} \mathrm{SiO}_{3}$ and $\mathrm{NaOH}$ were proportioned in a ratio of 2.5. Fly Ash was used as a binder instead of ordinary Portland cement-based paste to produce geopolymer concrete. The manufacturing of SCGC was supported by using the traditional trial and error concrete technology methods. $\mathrm{NaOH}$ flakes and $\mathrm{Na}_{2} \mathrm{SiO}_{3}$ solutions are shown in Figure 2. Fly ash content was also kept the same in both ECC and EGC mixed, and that translates Activator to fly ash (A/FA) ratio equal to 0.28 , which was less than the 0.45 ratio suggested by Zahid et al. [27].

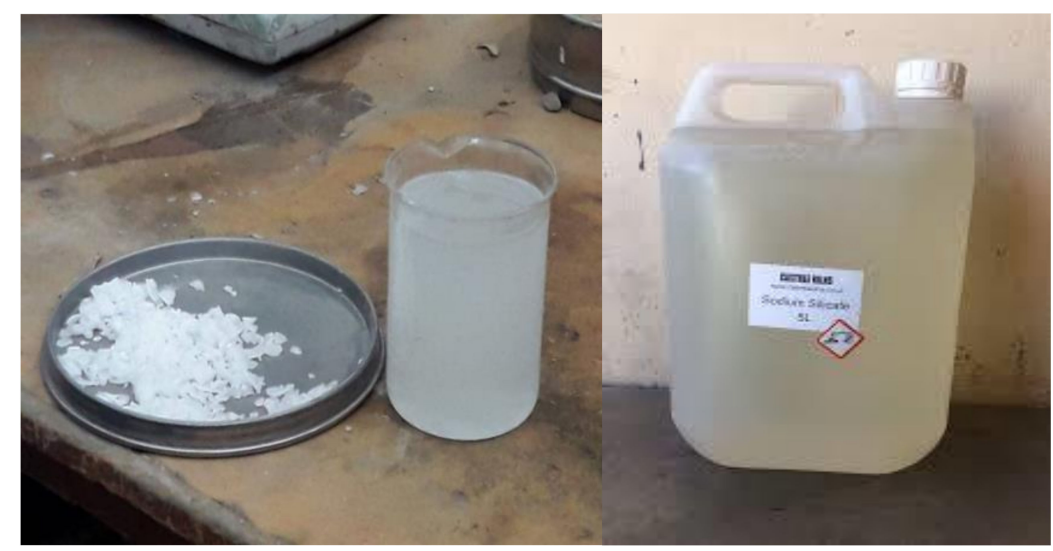

Figure 2. Alkaline Activators $\mathrm{NaOH}$ flakes and solution (on left side) and $\mathrm{Na}_{2} \mathrm{SiO}_{3}$ solution (on right side).

Several trial mixtures of SCGC were produced. The detail of final mixtures is given in Table 3. The mix ratio of "Fly Ash (FA)" to "Fine Aggregates" to "Coarse Aggregates" was 
kept as 1:2.125:2.375. The ratio of the alkaline solution to FA was kept constant at 0.5 for all mix proportions. The mix design for SCGC mixes was adopted from [1] to achieve a target strength of $28 \mathrm{MPa}$.

Table 3. Mix proportion and quantities for SCGC for $1 \mathrm{~m}^{3}$ concrete [1].

\begin{tabular}{|c|c|c|c|c|c|c|c|c|c|c|}
\hline \multirow{2}{*}{$\begin{array}{l}\text { Trial Mixing } \\
\text { Code }\end{array}$} & \multirow{2}{*}{$\begin{array}{c}\text { Fly Ash } \\
\left(\mathrm{kg} / \mathrm{m}^{3}\right)\end{array}$} & \multicolumn{2}{|c|}{ Coarse Agg. $\left(\mathrm{kg} / \mathrm{m}^{3}\right)$} & \multirow{2}{*}{$\begin{array}{l}\text { Fine Agg. } \\
\left(\mathrm{kg} / \mathrm{m}^{3}\right)\end{array}$} & \multirow{2}{*}{$\begin{array}{c}\mathrm{NaOH} \\
\left(\mathrm{kg} / \mathrm{m}^{3}\right)\end{array}$} & \multirow{2}{*}{$\begin{array}{c}\mathrm{Na}_{2} \mathrm{SiO}_{3} \\
\left(\mathrm{~kg} / \mathrm{m}^{3}\right)\end{array}$} & \multirow{2}{*}{$\begin{array}{c}\mathrm{SP} \\
\left(\mathrm{kg} / \mathrm{m}^{3}\right)\end{array}$} & \multirow{2}{*}{$\begin{array}{c}\text { Extra } \\
\text { Water }\left(\mathrm{kg} / \mathrm{m}^{3}\right)\end{array}$} & \multicolumn{2}{|c|}{ Curing } \\
\hline & & Natural & Recycled & & & & & & $\begin{array}{c}\text { Duration } \\
\text { (hrs). }\end{array}$ & $\begin{array}{c}\text { Temperature } \\
\left({ }^{\circ} \mathrm{C}\right)\end{array}$ \\
\hline SCGC-0 & 400 (FA) & 950 & - & 850 & $52(8 \mathrm{M})$ & 143 & $28(7 \%)$ & $60(15 \%)$ & 24 & 70 \\
\hline SCGC-30 & 400 (FA) & 665 & 285 & 850 & $52(8 \mathrm{M})$ & 143 & $28(7 \%)$ & $80(20 \%)$ & 24 & 70 \\
\hline
\end{tabular}

After a freshly prepared SCGC batch, L-box, slump-flow, J ring, and V-funnel tests were performed to determine the fresh state properties, as stated in [11]. The concrete samples were then cured at a constant temperature of $70{ }^{\circ} \mathrm{C}$ for $24 \mathrm{~h}$ to complete the process of geoploymerization, because the alumina-silicate-based materials with alkalis require heat curing to get activated [11]. It has been found from the literature that the rate of the geopolymerization process is higher at higher curing temperatures. This accelerates the hardening process of SCGC, and concrete specimens cured at $70{ }^{\circ} \mathrm{C}$ have higher compressive strength compared to those cured at a temperature greater or less than $70{ }^{\circ} \mathrm{C}[1]$.

\section{Experimental Tests, Results and Discussion}

\subsection{Fresh State Properties}

According to EFNARC [25], the fresh state properties, including filling ability and stability of SCC are defined by four key characteristics as highlighted in Table 4 . The slump-flow, V-funnel, and L-box tests were performed in this investigation. The following test methods as suggested by EFNARC [25] were used.

Table 4. Tests and allowable range for fresh state properties [25].

\begin{tabular}{|c|c|c|c|c|}
\hline \multirow{2}{*}{ Properties } & \multirow{2}{*}{ Test Method(s) } & \multirow{2}{*}{ Unit } & \multicolumn{2}{|c|}{ Allowable Range } \\
\hline & & & Minimum & Maximum \\
\hline Flowability & Slump-Flow (SF) Test & $\mathrm{mm}$ & 550 & 800 \\
\hline $\begin{array}{l}\text { Viscosity (a measure of the speed } \\
\text { of flow and assessed by the rate of } \\
\text { flow), VS or VF }\end{array}$ & $\begin{array}{l}\mathrm{T}_{500} \text { Slump-flow test } \\
\text { or V-funnel test }\end{array}$ & Sec & 2 & 5 \\
\hline Passing ability (PA) & L-box test & Sec & 6 & 12 \\
\hline Segregation (SR) & $\begin{array}{l}\text { Segregation resistance } \\
\text { (sieve) test }\end{array}$ & $\mathrm{h}_{2} / \mathrm{h}_{1}$ & 0.8 & 1.0 \\
\hline
\end{tabular}

The rheological or fresh state property tests for SCC- 0 and SCC-30 mixes were performed to examine the workability and are summarised in Tables 5 and 6. Similarly, the results for fresh state property tests performed on SCGC-0 and SCGC-30 are shown in Tables 7 and 8 . Tables $5-8$ also show the tested values along with the allowable ranges, which conforms to the EFNARC [25] of SCC and SCGC for structural application. From the results listed in Tables 5-8, it can be observed that the viscosity, passing ability, and segregation results of concrete were higher in SCC and SCGC mixes containing RCA (i.e., SCC-30 and SCGC-30 mixes) than those mixes containing NCA (i.e., SCC-0 and SCGC-0 mixes) but were within the EFNARC [25] limits for self-compacting concrete (SCC). The reason for higher results in SCGC mixes can be attributed to $\mathrm{Na}_{2} \mathrm{SiO}_{3}$ to $\mathrm{NaOH}$ ratio, which was 2.5. Salihi and Younis [21] reported that $\mathrm{Na}_{2} \mathrm{SiO}_{3}$ to $\mathrm{NaOH}$ ratio and the molarity of $\mathrm{NaOH}$ affect the fresh state properties of SCGC. The reported results in Tables 5-8 show that SCGC mix can be developed using RCA, as it satisfied the requirements of EFNARC [25]. 
Table 5. Properties, tests, and allowable range for different tests of SCC with $100 \%$ NCA.

\begin{tabular}{|c|c|c|c|c|c|}
\hline \multirow{2}{*}{ Properties } & \multirow{2}{*}{ Test Method(s) } & \multirow{2}{*}{ Resulted Value } & \multirow{2}{*}{ Unit } & \multicolumn{2}{|c|}{ Allowable Range } \\
\hline & & & & Minimum & Maximum \\
\hline Flowability & Slump-Flow (SF) Test & - & $\mathrm{mm}$ & 550 & 800 \\
\hline $\begin{array}{l}\text { Viscosity (a measure of the } \\
\text { speed of flow and assessed by } \\
\text { the rate of flow), VS or VF }\end{array}$ & $\begin{array}{c}T_{500} \text { Slump-flow test or } \\
\text { V-funnel test }\end{array}$ & 2.5 & Sec & 2 & 5 \\
\hline Passing ability (PA) & L-box test & 8 & Sec & 6 & 12 \\
\hline Segregation (SR) & $\begin{array}{l}\text { Segregation resistance } \\
\text { (sieve) test }\end{array}$ & 0.92 & $\mathrm{~h}_{2} / \mathrm{h}_{1}$ & 0.8 & 1.0 \\
\hline
\end{tabular}

Table 6. Properties, tests and allowable range for different tests of SCC with 30\% RCA.

\begin{tabular}{|c|c|c|c|c|c|}
\hline \multirow{2}{*}{ Properties } & \multirow{2}{*}{ Test Method(s) } & \multirow{2}{*}{ Resulted Value } & \multirow{2}{*}{ Unit } & \multicolumn{2}{|c|}{ Allowable Range } \\
\hline & & & & Minimum & Maximum \\
\hline Flowability & Slump-Flow (SF) Test & - & $\mathrm{mm}$ & 550 & 800 \\
\hline $\begin{array}{l}\text { Viscosity (a measure of the } \\
\text { speed of flow and assessed by } \\
\text { the rate of flow), VS or VF }\end{array}$ & $\begin{array}{c}T_{500} \text { Slump-flow test or } \\
\text { V-funnel test }\end{array}$ & 2.9 & Sec & 2 & 5 \\
\hline Passing ability (PA) & L-box test & 8.2 & Sec & 6 & 12 \\
\hline Segregation (SR) & $\begin{array}{l}\text { Segregation resistance } \\
\text { (sieve) test }\end{array}$ & 0.98 & $\mathrm{~h}_{2} / \mathrm{h}_{1}$ & 0.8 & 1.0 \\
\hline
\end{tabular}

Table 7. Properties, tests and allowable range for different tests of SCGC with $100 \%$ NCA.

\begin{tabular}{|c|c|c|c|c|c|}
\hline \multirow{2}{*}{ Properties } & \multirow{2}{*}{ Test Method(s) } & \multirow{2}{*}{ Resulted Value } & \multirow{2}{*}{ Unit } & \multicolumn{2}{|c|}{ Allowable Range } \\
\hline & & & & Minimum & Maximum \\
\hline Flowability & Slump-Flow (SF) Test & - & $\mathrm{mm}$ & 550 & 800 \\
\hline $\begin{array}{l}\text { Viscosity (a measure of the } \\
\text { speed of flow and assessed by } \\
\text { the rate of flow), VS or VF }\end{array}$ & $\begin{array}{c}T_{500} \text { Slump-flow test or } \\
\text { V-funnel test }\end{array}$ & 2.8 & Sec & 2 & 5 \\
\hline Passing ability (PA) & L-box test & 8.2 & Sec & 6 & 12 \\
\hline Segregation (SR) & $\begin{array}{l}\text { Segregation resistance } \\
\text { (sieve) test }\end{array}$ & 0.76 & $\mathrm{~h}_{2} / \mathrm{h}_{1}$ & 0.8 & 1.0 \\
\hline
\end{tabular}

Table 8. Properties, tests and allowable range for different tests of SCGC with 30\% RCA.

\begin{tabular}{|c|c|c|c|c|c|}
\hline \multirow{2}{*}{ Properties } & \multirow{2}{*}{ Test Method(s) } & \multirow{2}{*}{ Resulted Value } & \multirow{2}{*}{ Unit } & \multicolumn{2}{|c|}{ Allowable Range } \\
\hline & & & & Minimum & Maximum \\
\hline Flowability & Slump-Flow (SF) Test & - & $\mathrm{mm}$ & 550 & 800 \\
\hline $\begin{array}{l}\text { Viscosity (a measure of the } \\
\text { speed of flow and assessed by } \\
\text { the rate of flow), VS or VF }\end{array}$ & $\begin{array}{c}T_{500} \text { Slump-flow test or } \\
\text { V-funnel test }\end{array}$ & 3.3 & Sec & 2 & 5 \\
\hline Passing ability (PA) & L-box test & 8.8 & $\mathrm{Sec}$ & 6 & 12 \\
\hline Segregation (SR) & $\begin{array}{l}\text { Segregation resistance } \\
\text { (sieve) test }\end{array}$ & 0.79 & $\mathrm{~h}_{2} / \mathrm{h}_{1}$ & 0.8 & 1.0 \\
\hline
\end{tabular}




\subsection{Hardened State Properties}

The hardened state properties, including compression and split tension tests, were determined after a period of 28 days of curing. Each test was performed on 3 specimens for each design mix, 12 cylinders of the size $100 \mathrm{~mm}$ diameter and $200 \mathrm{~mm}$ height were cast, out of which 6 were prepared using mix type "R0" and the remaining were cast from mix type "R30". Out of 6 cylinders, 3 cylinders were dedicated for the compression test ( 3 cylinders for each design mix), while the rest were tested for split tension test ( 3 cylinders for each design mix). After $24 \mathrm{~h}$ of casting, all 12 cylinders were unmoulded and soaked in a water tank for a curing period of 28 days.

\subsubsection{Compression Test}

The compression test was performed after the completion of the curing period of 28 days using three replicate specimens of size $100 \mathrm{~mm}$ diameter and $200 \mathrm{~mm}$ height for each type of design mix according to ASTM C39/C39M-18 [28] of each type of concrete. The test was performed at a loading rate of $0.05 \mathrm{~mm} / \mathrm{min}(0.0019685 \mathrm{in} . / \mathrm{min})$, using a compression testing machine of $1000 \mathrm{kN}$ (224.8 kips) capacity. The cylindrical specimens were air-dried before the testing for a few hours and the ends were capped with the sulphur compound to ensure the uniform distribution of the compressive load between cylinders and machine as recommended in ASTM C617/C617M [29]. The testing setup is shown in Figure 3.

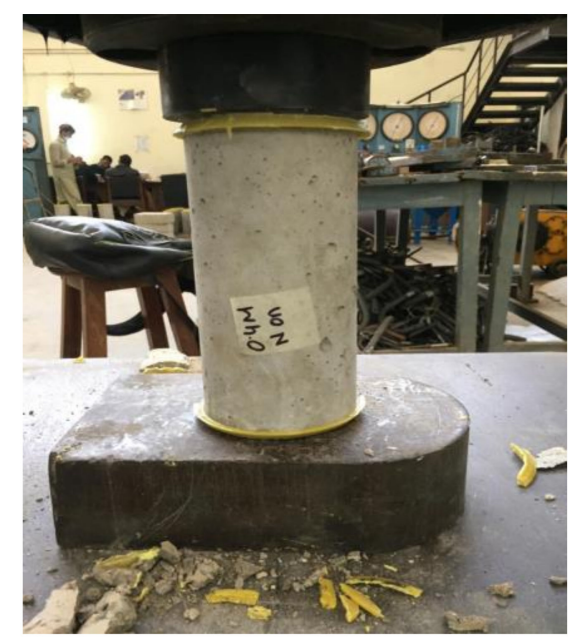

Figure 3. Experimental setup for compression test of SCC and SCGC specimens.

The average compressive strength results of SCC and SCGC mixes are presented in Figure 4 . The reported results in the following figure are found to be consistent with the results reported by Panda et al. and Xie et al. [30,31]. The results show that the compressive strength of concrete decreases when NCA are partially or fully replaced with RCA.

In Figure 4, it can be observed that SCC without recycled aggregate (SCC-0 mix) possesses the maximum compressive strength at 28 days, which has a value of $27.72 \mathrm{MPa}$. It can also be observed that the compressive strength for SCC- 0 and SCGC- 0 mixes is $20 \%$ and $13.45 \%$ higher than SCC-30 and SCGC-30, respectively, at 28 days. The increase in the compressive strength control mix SCC-0 was 33\% higher than SCC-30 mix. Similarly, the increase in the compressive strength control mix SCGC-0 was $38.3 \%$ higher than SCGC-30 mix. This infers that the decrease in the compressive strength using 30\% RCA is more than 30\% in SCC and SCGC mixes and these results are contradicting the past research study [22] conducted at the Department of Civil Engineering, NED University of Engineering \& Technology using conventional concrete. It can be further concluded that the use of RCA in SCC mix is more productive in terms of strength and cost of material rather than SCGC mix, as the strength of SCGC-30 mix is much lower than that of SCC-30. 
The trend of results reported in Figure 4 cannot be compared with the results reported in the literature due to the unavailability of studies on the comparison of SCC and SCGC; however, the reason for reduced compressive strength can also be associated with the weak bond between old mortar attached to recycled aggregate and new concrete.

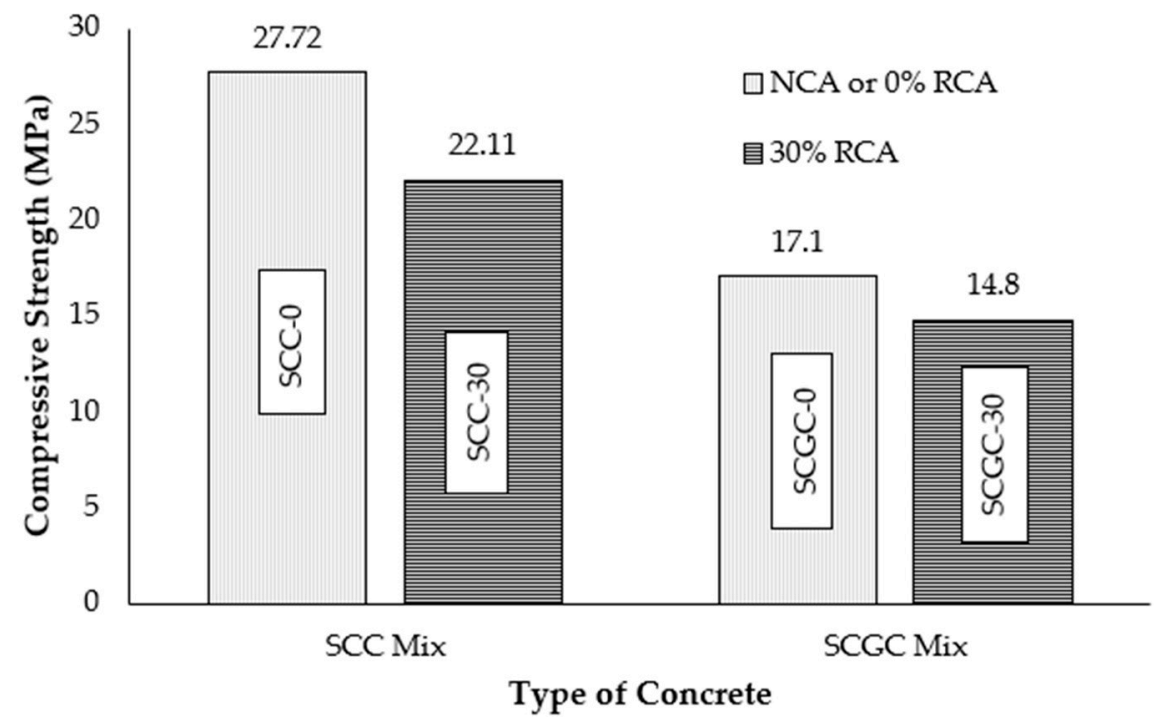

Figure 4. Average compressive strength of SCC and SCGC mixes at 28 days.

\subsubsection{Split Tension Test}

The split tension test was performed using three replicate specimens of SCC and SCGC mixes following ASTM C496/C496M-17 standard [32]. Figure 5 shows the testing setup of the split tension test. The test was performed using a compression testing machine of $500 \mathrm{kN}$ (112.4 kips) capacity. Once the cylindrical specimens were dried, diametrical lines on the two ends of the specimen were drawn using a marker to verify that both ends are in the same axial place. After that, the load was continuously applied without shock at a rate of approximately $10 \mathrm{kips} /$ minute (22 kips/minute). Once the specimen bifurcated, the breaking load was noted. The average split tensile strength results are presented in Figure 6, which are consistent with the results reported by Panda et al. and Xie et al. [30,31].

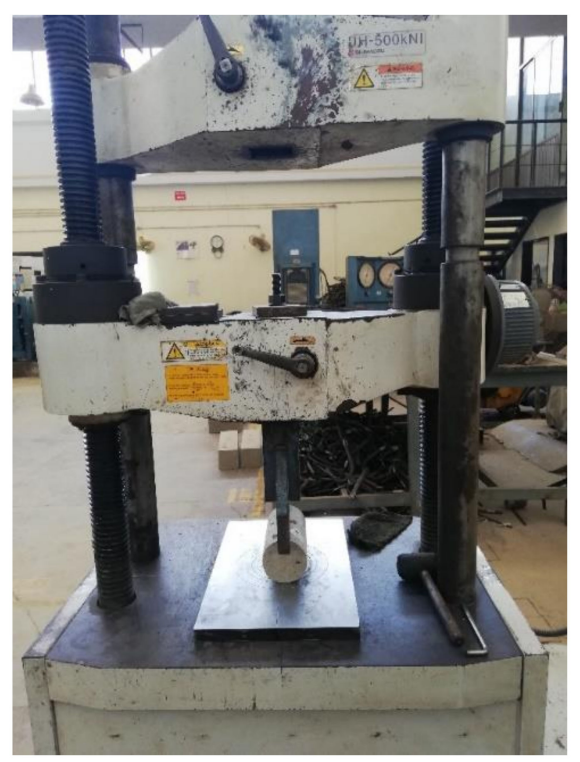

Figure 5. Experimental setup for the split tension test of SCC and SCGC specimens. 


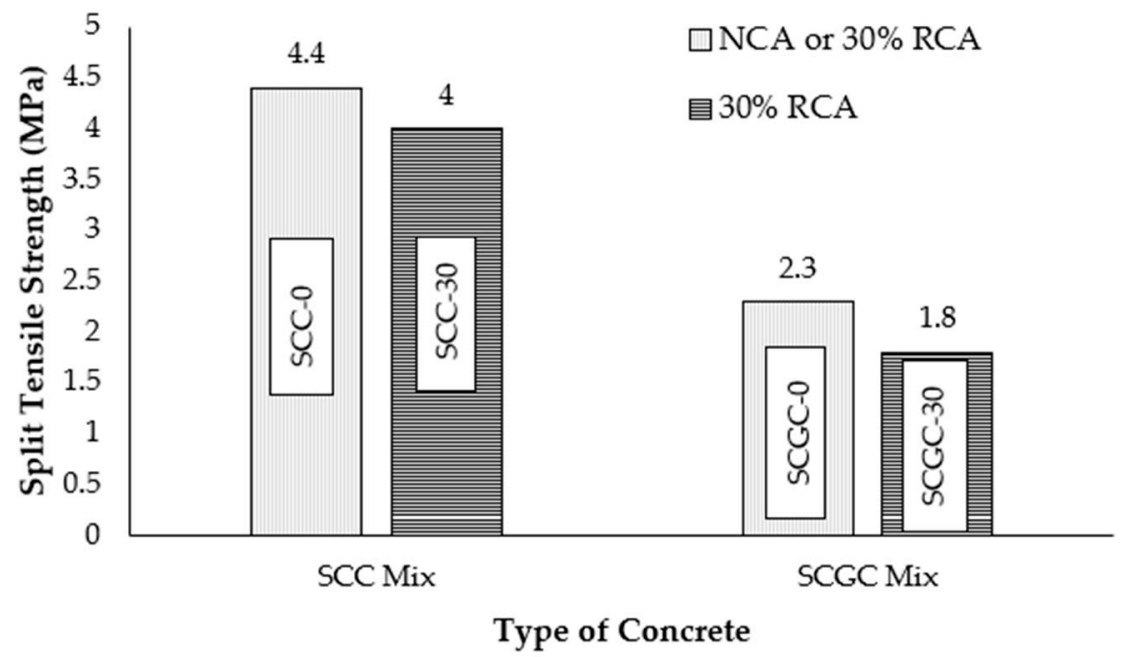

Figure 6. Average split tensile strength of SCC and SCGC mixes for at 28 days.

Results reported in Figure 6 indicate that the split tensile strength of concrete decreases when natural aggregates are replaced with recycled aggregates. In Figure 6, it can be observed that the maximum split tensile strength obtained for SCC- 0 at 28 days was 4.4 MPa. The split tensile strength for SCC-0 and SCC-30 mixes was $9 \%$ and $21.74 \%$ higher than SCGC-0 and SCGC-30 mixes, respectively. The percentage increase in the split tensile strength of SCC- 0 mix was $47.73 \%$ compared to SCC-30 whereas the increase in the split tensile strength of SCGC- 0 mix was 55\% compared to SCGC-30. The reason for reduced split tensile strength can be related to the reduced compressive strength of both concretes. Moreover, the use of RCA in SCGC (i.e., SCGC-30 mix) is less cost-effective and lower strength was achieved compared to SCC. The split tensile strength of SCC mixes is much higher than the SCGC mixes. Similar to the compressive strength results, the trend of results reported in Figure 6 cannot be compared with the results reported in the literature due to the unavailability of studies on the comparison of SCC and SCGC.

\subsection{Durability Properties}

Concrete, when exposed to an aggressive environment, is affected by the deleterious action of carbon dioxide $\left(\mathrm{CO}_{2}\right)$, sulphate, chloride, alkalis, water, oxygen, acids, etc. Such influences from the environment are related to the durability of the concrete structure. Therefore, durability tests need to be carried out to access the influence of these parameters on the performance of concrete. The relevant durability tests are summarised in Table 9, along with the standards and specimen's detail. For each test, triplicate specimens were tested, and the averaged result is reported.

Table 9. Durability tests performed on SCC and SCGC.

\begin{tabular}{|c|c|c|}
\hline \multirow{2}{*}{ Durability Test and Standards } & \multicolumn{2}{|l|}{ Specimen Details } \\
\hline & Specimen Size & No. of Specimens \\
\hline DIN-1048: Hydraulic Permeability [33] & $100 \times 100 \times 100 \mathrm{~mm}$ & 3 \\
\hline CEN Test: Carbonation [34] & 100 dia. $\times 200 \mathrm{~mm}$ height & 3 \\
\hline $\begin{array}{l}\text { ASTM C876: Half-Cell Potential test after } \\
\text { exposure in salt spray machine [35] }\end{array}$ & \multirow{2}{*}{$\begin{array}{l}100 \text { dia. And } 200 \mathrm{~mm} \text { height specimen where a } 100 \mathrm{~mm} \text { length of } 10 \mathrm{~mm} \\
\text { dia. steel bar was embedded inside the specimen and } 350 \mathrm{~mm} \text { length was } \\
\text { exposed outside, i.e., overall length of steel bar was } 450 \mathrm{~mm}\end{array}$} & \multirow[t]{2}{*}{3} \\
\hline ASTM C900: Pull-Out Test [36] & & \\
\hline
\end{tabular}

\subsubsection{Hydraulic Permeability}

The property of concrete associated with the flow rate of liquid into its pores is permeability. This property is important for concrete structures performance when exposed 
to the marine environment. The procedure for the permeability test has been described in DIN-1048 [33]. The automatic concrete water permeability apparatus with four cells (refer to Figure 7) was used for permeability tests for periods of 28, 90, 180, 365, and 720 days, respectively. The cube specimen size was $100 \times 100 \times 100 \mathrm{~mm}$ and after casting the specimens were placed in a moist curing tank for 28 days and then placed in the laboratory environment for periods of 28, 90, 180, 365, and 720 days. For each specified time interval, three specimens were placed in an automatic concrete water permeability apparatus, as shown in Figure 5. The specimens were placed in the apparatus at a hydraulic pressure of 5 bar $(10 \mathrm{~cm}$ of water column) for $72 \mathrm{~h}(259,200 \mathrm{~s})$. After completion of $72 \mathrm{~h}$, the samples were taken out and weighed again.

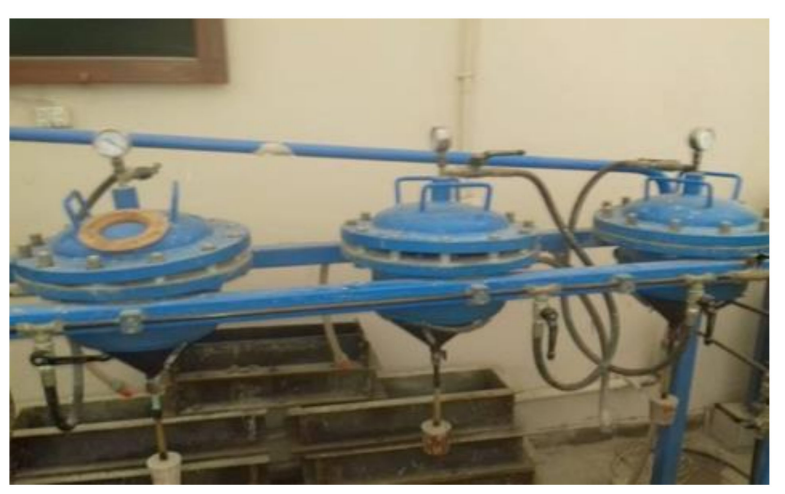

Figure 7. Automatic concrete water permeability apparatus.

The sample is then split into two parts by applying a compressive force to examine the water penetration depth. The cracked surface (refer to Figure 8) indicates that water penetrated the region near to edges, as highlighted on the specimen whereas, the region below the highlighted portion is the area where water did not penetrate.

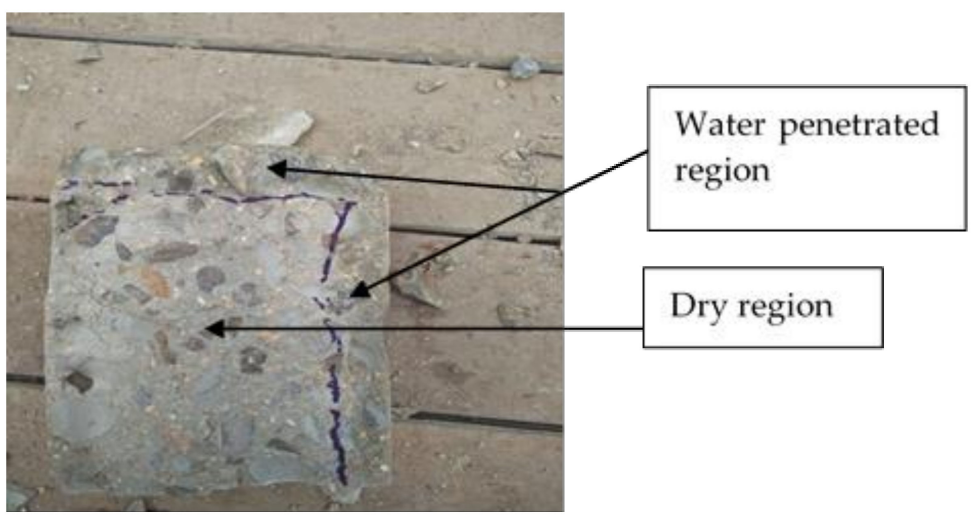

Figure 8. Cracked surface of concrete specimen indicating water penetration depth.

The results of water penetration tests of SCC and SCGC mixes are presented in Figures 9 and 10, which demonstrate that there is an increment in the water penetration depth at all ages using 30\% RCA content in the SCC-30 and SCGC-30 mixes as compared to the control SCC-0 and SCGC-0 mixes. These results are consistent with the results reported by Adnan et al. [37] and Olivia and Nikraz [18], which demonstrated that recycled aggregate concrete manifests higher water permeability compared to natural aggregate concrete. From Figures 9 and 10, it can be observed that the increase in water penetration depth was higher in mix R30 compared to mix R0 at 28, 90, 180, 365 and 720 days due to the adhesion of mortar from previous concrete to the recycled coarse aggregates. The adhesion of old concrete with the coarse aggregates is responsible for higher water permeability in mix R30 as compared to mix R0, which increased the water absorption. 


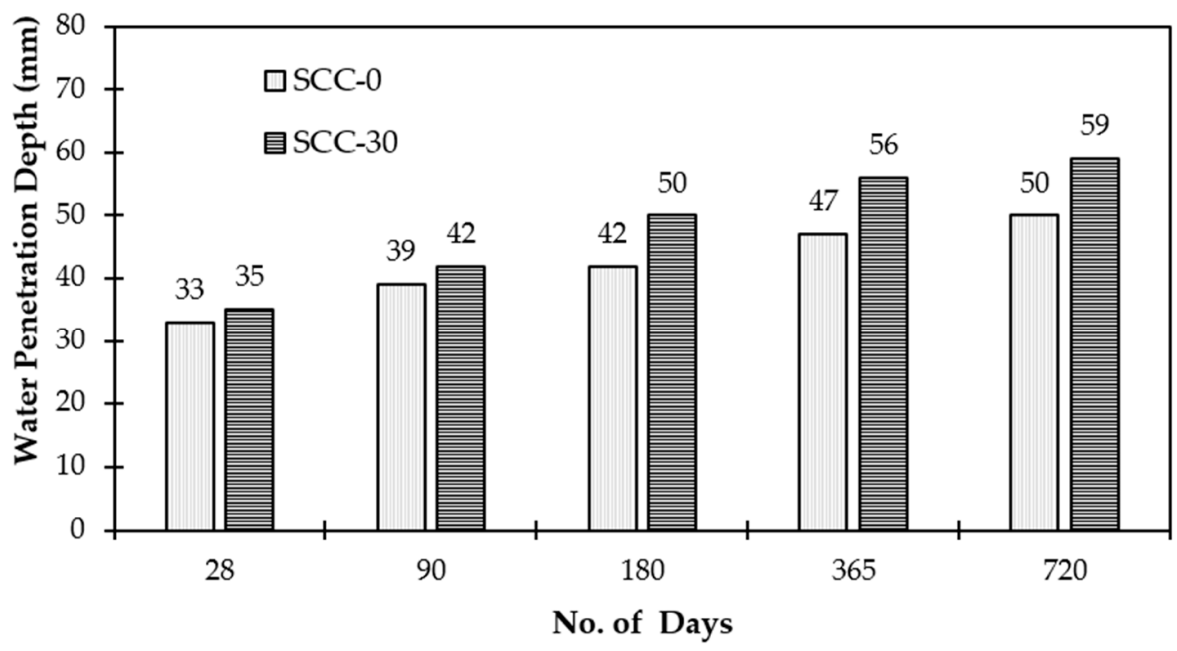

Figure 9. Water penetration depth in SCC samples at different ages.

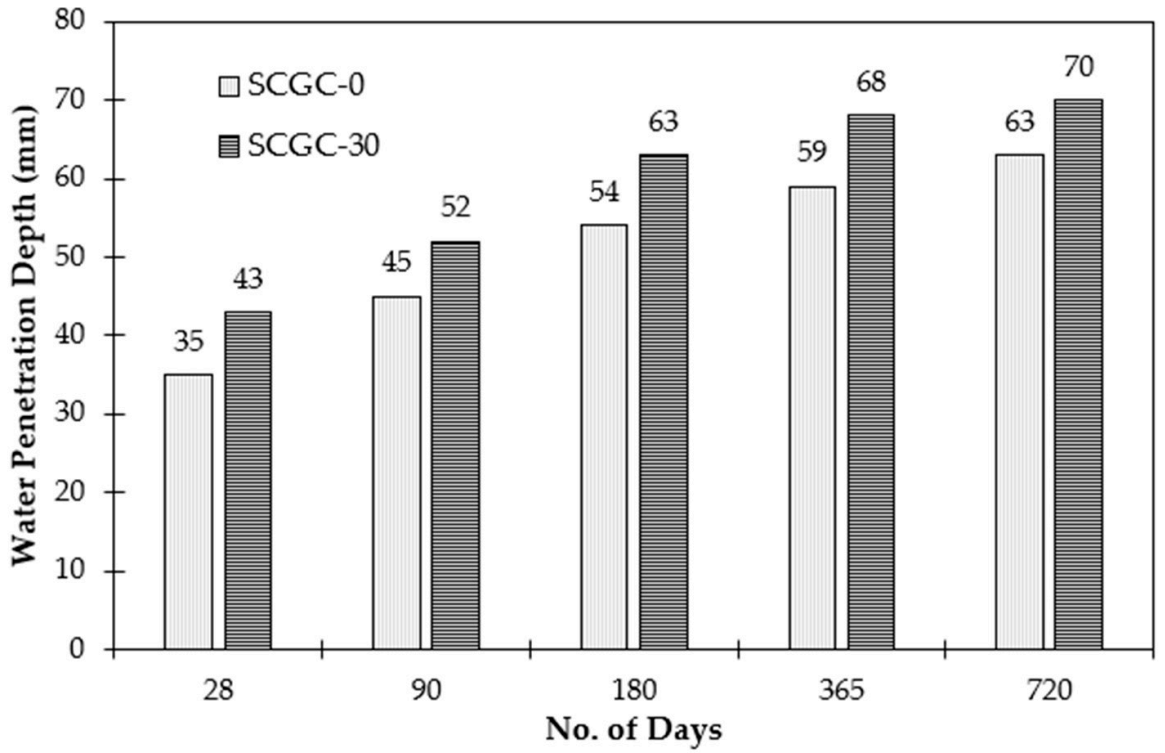

Figure 10. Water penetration depth in SCGC samples at different ages.

From Figures 9 and 10, it can be observed that the water penetration depth for SCGC-0 mix was found to be $5.71 \%, 7.142 \%, 16 \%, 16.07 \%$, and $15.25 \%$ higher than SCC- 0 at 28, 90, 180,365 , and 720 days, respectively. Similarly, the increase in the water penetration depth for SCGC-30 mix was found to be $18.6 \%, 13.46 \%, 14.29 \%, 13.24 \%$, and $10 \%$ higher than SCC-30 mix at 28, 90, 180, 365, and 720 days, respectively.

The increase in the water penetration depth for SCC-30 mix compared to SCC-0 mix was $5.71 \%, 13.33 \%, 22.22 \%, 20.34 \%$, and $20.63 \%$ at $28,90,180,365$, and 720 days. Nevertheless, the increase in the water penetration depth for SCGC-30 mix compared to SCGC-0 mix was $18.6 \%, 19.23 \%, 20.64 \%, 17.65 \%$, and $15.71 \%$ at $28,90,180,365$, and 720 days, respectively.

These results indicate that SCC is more resistant to water penetration compared to SCGC with and without containing RCA. Furthermore, it was found that the percentage difference in the depth of water penetration in SCC is less than in SCGC mixes. Therefore, it can be concluded that SCGC containing RCA is unsuitable for use in hydraulic structures. Olivia and Nikraz [18] emphasised that an alkaline solution tends to increase water absorption in a mixture of concrete. The higher amount of alkaline solution produces a porous geopolymer gel and the higher quantity of sodium silicate produces large pore sizes, which 
may then influence the water permeability of concrete. This could be the reason that SCGC mixes displayed higher water permeability than SCC mixes.

\subsubsection{Accelerated Carbonation Test}

Carbonation is the formation of carbonic acid when carbon dioxide $\left(\mathrm{CO}_{2}\right)$ gas dissolves in water $\left(\mathrm{H}_{2} \mathrm{O}\right)$ present in the pores of concrete. Carbonation makes the concrete acidic over time as it decreases its $\mathrm{pH}$, which increases the chances of steel reinforcement corrosion. To examine this phenomenon in SCC and SCGC mixes using NCA and 30\% RCA, 3 cube specimens of $100 \times 100 \times 100 \mathrm{~mm}$ in size were cast. The samples were covered with an impermeable plastic sheet for another $24 \mathrm{~h}$. The samples were then removed from the mould and kept uncovered for 3 days. The curing method suggested in the CEN test method [34] and followed by Jones et al. [38] was used for measurement of the carbonation depth of hardened concrete. The triplicate specimens for each design mix were placed in a carbonation chamber shown in Figure 11. The parameters determined from the CEN test are summarised in Table 10. Specimens were placed in the accelerated carbonation chamber for $11.2,33.6,67.2,134.4$ and $268.8 \mathrm{~h}$ for accelerated exposure equivalent to 28,90 , 180,365 - and 720-days exposure to the natural environment for the parameters mentioned in Table 6. These test durations were derived from Dhir et al.'s statement given in the guidelines of accelerated carbonation testing of concrete provided by Dunster [39].

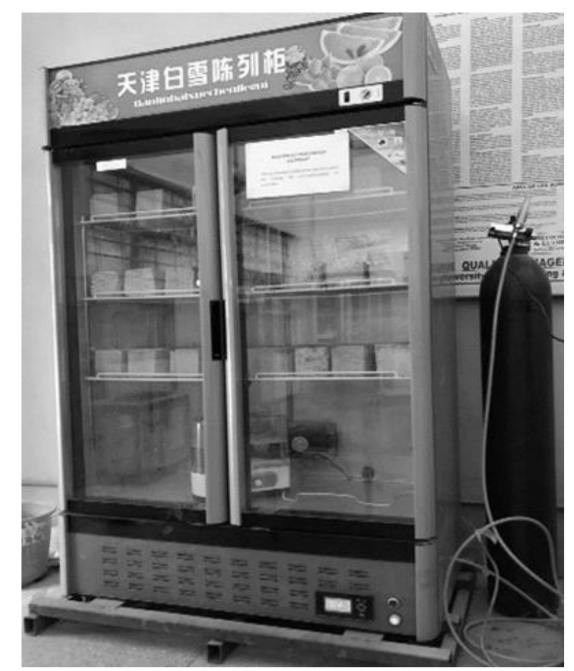

Figure 11. Accelerated concrete carbonation test chamber.

Table 10. Parameters provided in Carbonation Chamber [39].

\begin{tabular}{cc}
\hline Temperature & $20 \pm 2{ }^{\circ} \mathrm{C}$ \\
\hline Relative humidity & $65 \pm 5 \%$ \\
\hline $\mathrm{CO}_{2}$ concentration & $350+50 \mathrm{ppm}$ \\
\hline
\end{tabular}

After exposure, specimens were split into two pieces and phenolphthalein indicator was sprayed on the cracked surface. The surface or region where carbon dioxide $\left(\mathrm{CO}_{2}\right)$ gas penetrated remained colourless after spraying phenolphthalein and the pink colour surface indicated the non-carbonated region [24,37], as shown in Figure 12. The test results of accelerated carbonation for SCC and SCGC mixes containing NCA and RCA are shown in Figures 13 and 14, which are consistent with the results reported by Singh and Singh [40]. It can be seen in the following Figures that the carbonation depth of SCC and SCGC mixes containing RCA is relatively higher than those containing NCA, which may be due to the higher content of paste and smaller aggregate content in SCC and SCGC mixes containing 
RCA (i.e., SCC-30 and SCGC-30), which led to more penetration access to the $\mathrm{CO}_{2}$ as compared to SCC and SCGC mixes containing NCA (i.e., SCC-0 and SCGC-0).

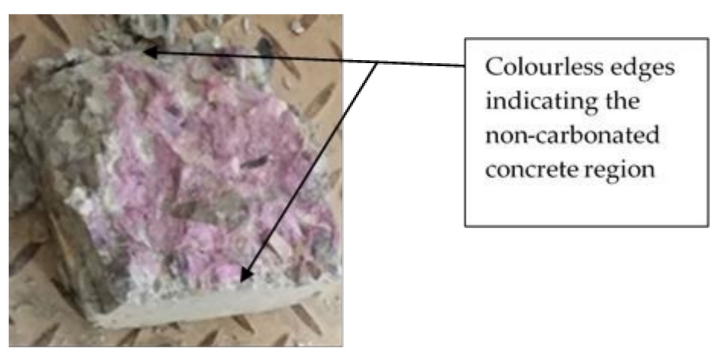

Figure 12. Cracked surface of concrete indicating carbonated and non-carbonated surface after phenolphthalein spray.

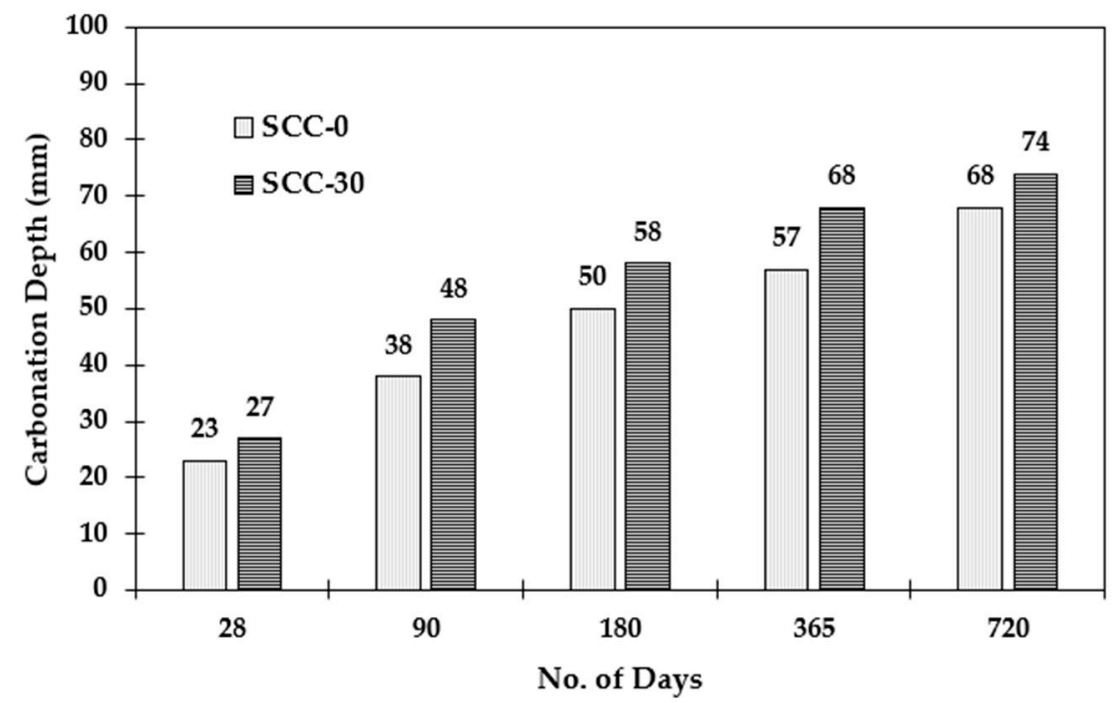

Figure 13. Carbonation depth in SCC samples at different ages.

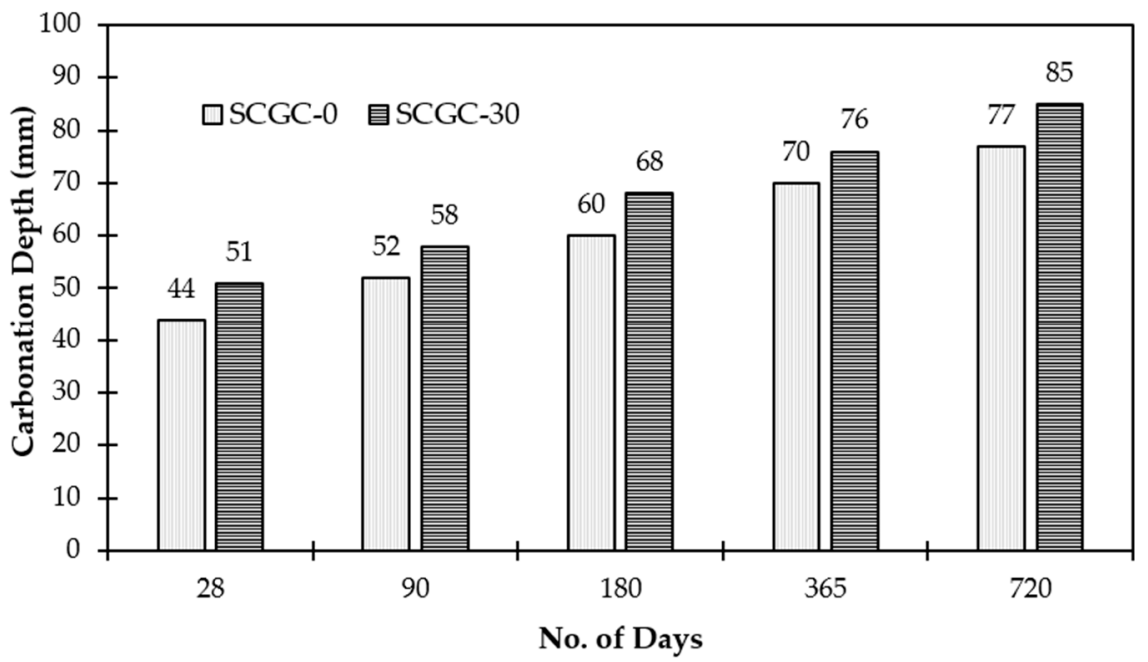

Figure 14. Carbonation depth in SCGC samples at different ages.

Figures 13 and 14 indicate that the SCC mix is more resistant to the penetration of $\mathrm{CO}_{2}$ gas due to less water content and reduced permeability as compared to SCGC. The overall results of carbonation depth for SCGC mixes were higher than SCC mixes, indicating the higher porosity in the SCGC mixes. The increase in carbonation depth in SCGC mix 
containing NCA (i.e., SCGC-0) compared to SCC-0 mix was $14.8 \%, 20.83 \%, 13.8 \%, 16.18 \%$ and $8.1 \%$ at $28,90,180,365$, and 720 days, respectively; however, the increase in carbonation depth in SCGC mix containing RCA (i.e., SCGC-30) compared to SCC-30 mix was 13.73\%, $10.34 \%, 11.76 \%, 7.89 \%$ and $9.41 \%$ at the same time period.

The increase in the carbonation depth for SCC-30 mix compared to SCC-0 mix was $47.73 \%, 26.92 \%, 16.67 \%, 18.57 \%$, and $11.69 \%$ at $28,90,180,365$, and 720 days, respectively. Nevertheless, the increase in the water penetration depth for SCGC-30 mix compared to SCGC-0 mix was $47.1 \%, 17.24 \%, 14.71 \%, 10.53 \%$, and $12.94 \%$ at $28,90,180,365$, and 720 days, respectively.

These results indicate that SCC is more resistant to $\mathrm{CO}_{2}$ penetration compared to SCGC with and without containing RCA. Furthermore, the reason for lower carbonation resistance in SCGC mixes can also be associated with the presence of AAS. Shi et al. [41] reported that the carbonation resistance of alkaline activator solution (AAS) mortars is lower than that of ordinary Portland cement mortars due to silicate modulus (MS), which is the ratio of $\mathrm{SiO}_{2}$ to $\mathrm{Na}_{2} \mathrm{O}$ and influences the carbonation resistance. They [41] reported that the excess of $\mathrm{Na}_{2} \mathrm{O}$ content in the pore solution due to high alkali dosage (about 15\%) which unable to precipitate become more susceptible to carbonation. Thus, it may infer that further investigation is needed to investigate the reason for lower carbonation resistance.

\subsubsection{Salt Spray and Half-Cell Potential Test}

Salt Spray (Fog) apparatus/chamber is the equipment that exposes specimens to an environment similar to that due to exposure to the marine environment. Salt Spray (Fog) apparatus/chamber is used for exposure equivalent to the marine environment in which the exposed specimens for tested for half-cell potential. The relevant standard for salt spray apparatus is ASTM B117 [42]. Test samples in the form of cylinders of $100 \mathrm{~mm}$ dia. and $200 \mathrm{~mm}$ height with $450 \mathrm{~mm}$ long steel bar were placed in the carbonation chamber for $11.2,33.6,67.2,134.4$, and $268.8 \mathrm{~h}$ for accelerated exposure equivalent to $28,90,180$, 365 and 720 days of exposure to the natural environment in the coastal areas of Karachi, Pakistan. Out of $450 \mathrm{~mm}$ long bar, $100 \mathrm{~mm}$ length was embedded inside the concrete cylinder while $350 \mathrm{~mm}$ length was outside the cylinder. The length of the bar was limited due to the chamber size and specimen's placement (refer to Figure 15). The bars were coated to avoid corrosion on bars due to the salt spray. Corrosion was only allowed through concrete. The operating parameters for salt spray (Fog) apparatus/chamber are the average actual temperature, humidity, and wind pressures measured at the coastal areas of Karachi, Pakistan.

After exposure to $\mathrm{NaCl}$ solution in Salt spray (fog) apparatus/chamber, the specimens were tested for half-cell potential to assess the corrosion of embedded reinforcement bar in concrete due to penetration of chloride ions in terms of potential difference. The method employed was ASTM C876 [35].

The results of potential difference in SCC and SCGC mixes are shown in Figures 16 and 17. Figure 16 shows that the potential difference value in SCC-30 mix is $46.9 \%, 50 \%, 36.39 \%$, $32.43 \%$, and $27.5 \%$ higher than SCC-0 mix at 28, 90, 180, 365, and 720 days; however, Figure 17 shows that the potential difference in SCGC-30 mix is $11.6 \%, 8.29 \%, 16.4 \%$, $10.91 \%$, and $10.34 \%$ higher than SCGC-0 mix at 28, 90, 180, 365, and 720 days, respectively.

The potential difference values for SCGC-0 and SCGC-30 mixes were higher than SCC-0 and SCC-30 mixes.

Using 30\% RCA, the potential difference of SCC-30 mix is $57.19 \%, 64.29 \%, 49.77 \%$, $48.98 \%$, and $44.23 \%$ higher than SCC-0 mix at 28, 90, 180, 365, and 720 days, respectively. Similarly, the potential difference of SCGC-30 mix is $28.73 \%, 34.49 \%, 33.98 \%, 32.73 \%$, and $31.03 \%$ higher than SCGC-0 mix at 28, 90, 180, 365, and 720 days, respectively. 


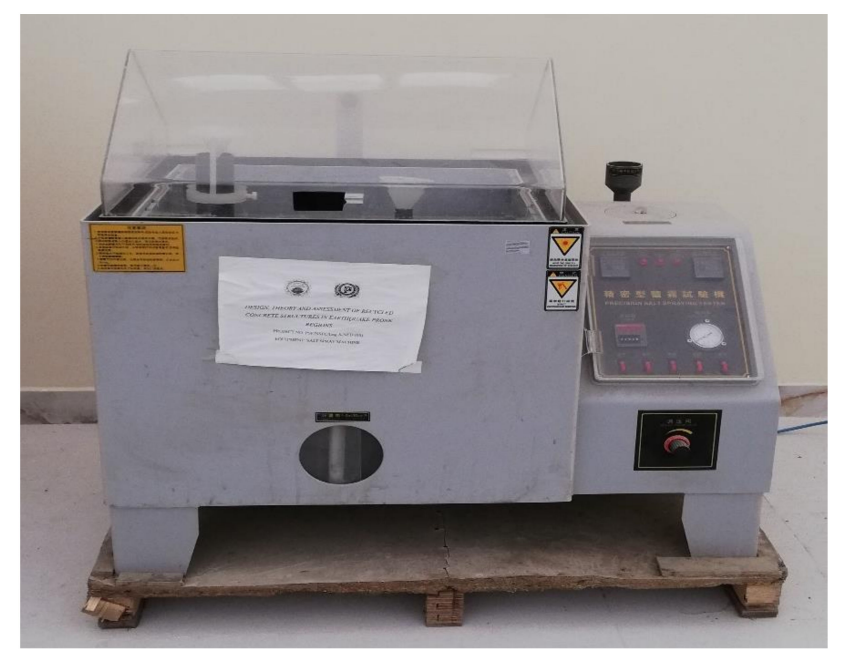

Figure 15. Exposure of specimens in Salt spray test machine.

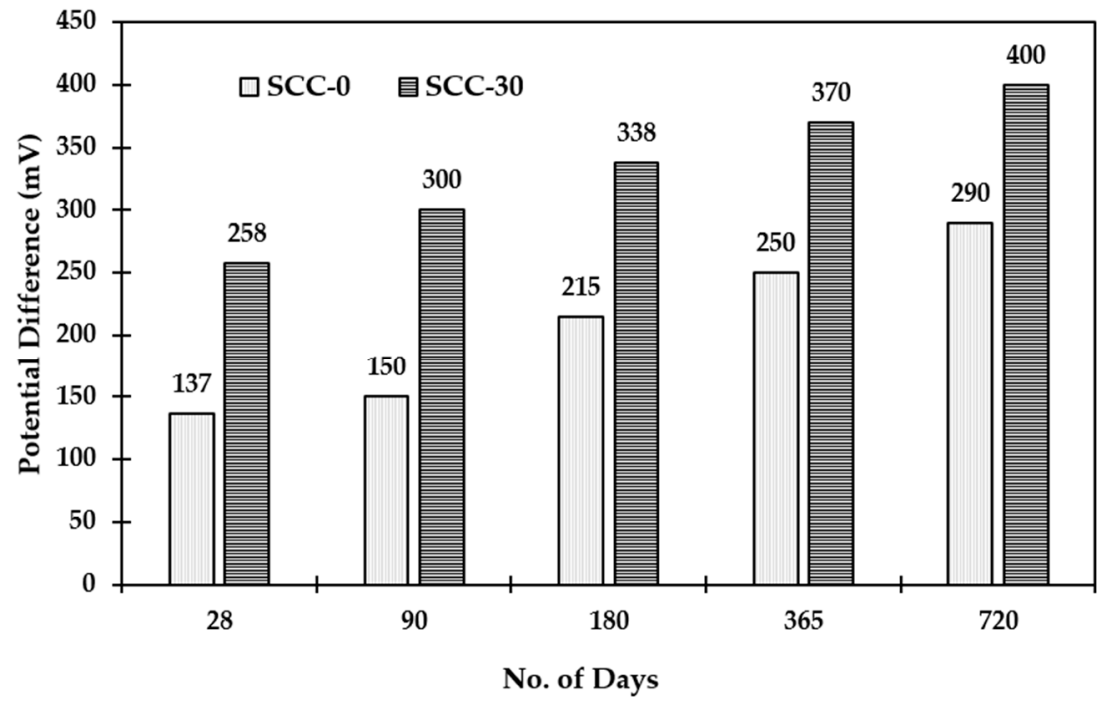

Figure 16. Half-cell potential test results of SCC samples at different ages.

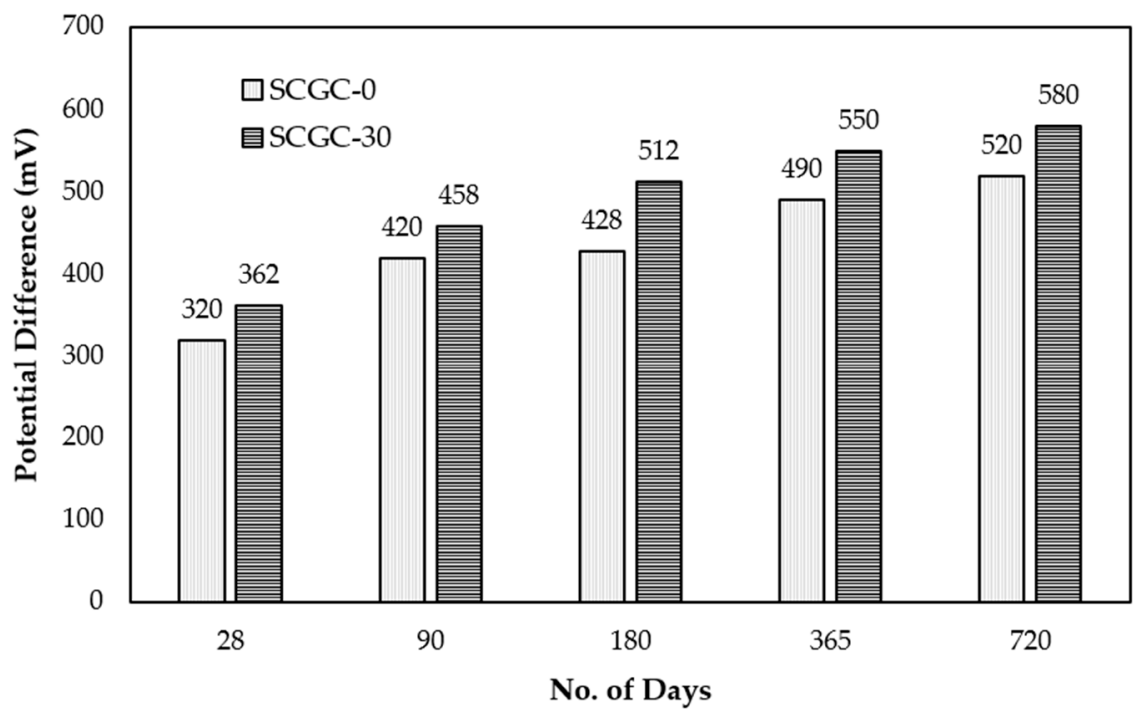

Figure 17. Half-cell potential test results of SCGC samples at different ages. 
From Figure 16, it can be concluded that the SCC mixes exhibited lower potential difference due to a lower conductivity resulting from less penetration of chloride ions in SCC- 0 as compared to SCC-30. Whereas, the potential difference in Figure 17 is greater in SCGC-0 and SCGC-30 mixes as compared to SCC- 0 and SCC-30, because more voids and water content favours the penetration of chloride ions and increase in the conductivity in SCGC. It can be concluded that SCGC is less resistant to penetration of chloride ions and consequent increase in conductivity compared to SCC. This behaviour is due to the presence of more pores in the structure of SCGC relative to SCC mixes. Due to the higher conductivity, which is consistent with higher chloride penetration in concrete, it cannot be recommended for hydraulic structures as the chances of corrosion of steel reinforcement are more which may lead to the loss of bond between concrete and the steel bar.

\subsubsection{Pull-Out Test}

The purpose of pull-out test is to assess the bond strength of steel and concrete which may get influenced by the replacement percentage of coarse aggregates and the exposure to the salt spray which may penetrate chloride ions in concrete. The test was conducted on concrete cylinders exposed to salt spray to examine the influence of chloride ion penetration on steel and concrete bonds. Concrete cylinders of $100 \mathrm{~mm}$ diameter and $200 \mathrm{~mm}$ height with $450 \mathrm{~mm}$ long steel reinforcing bar embedded in the cylinder in which $100 \mathrm{~mm}$ was outside the cylinder and the remainder inside were exposed for 28, 90, 180, 365, and 720 days. The exposed bars were pulled out and the strength of hardened concrete was determined by measuring the force required to pull the steel bar embedded in a concrete specimen [36], as shown in Figures 18 and 19.

From the following Figures, it can be seen that the pull-out strength of SCC mixes is higher than the SCGC mixes. The SCC-0 mix (with 100\% NCA) offers a pull-out strength of $12.82 \%, 16.1 \%, 22.27 \%, 30 \%$, and $45.45 \%$ higher than SCC-30 mix (with $30 \%$ RCA) at $28,90,180,365$, and 720 days, respectively. However, the pull-out strength in SCGC-0 mix containing NCA was found as higher at $25.89 \%, 22.1 \%, 35 \%, 22.92 \%$, and $43.59 \%$, respectively than SCGC-30 at 28, 90, 180, 365, and 720 days.

Using NCA, the pull-out strength of SCC-0 mix is $28.21 \%, 29.51 \%, 18.18 \%, 20 \%$ and $11.36 \%$ higher than SCGC-0 mix at 28, 90, 180, 365, and 720 days, respectively. Whereas, the pull-out strength of SCC-30 mix (using 30\% RCA) is 38.97\%, 34.57\%, 31.58\%, $11.9 \%$, and $8.3 \%$ higher than SCGC-30 mix at 28, 90, 180, 365, and 720 days, respectively.

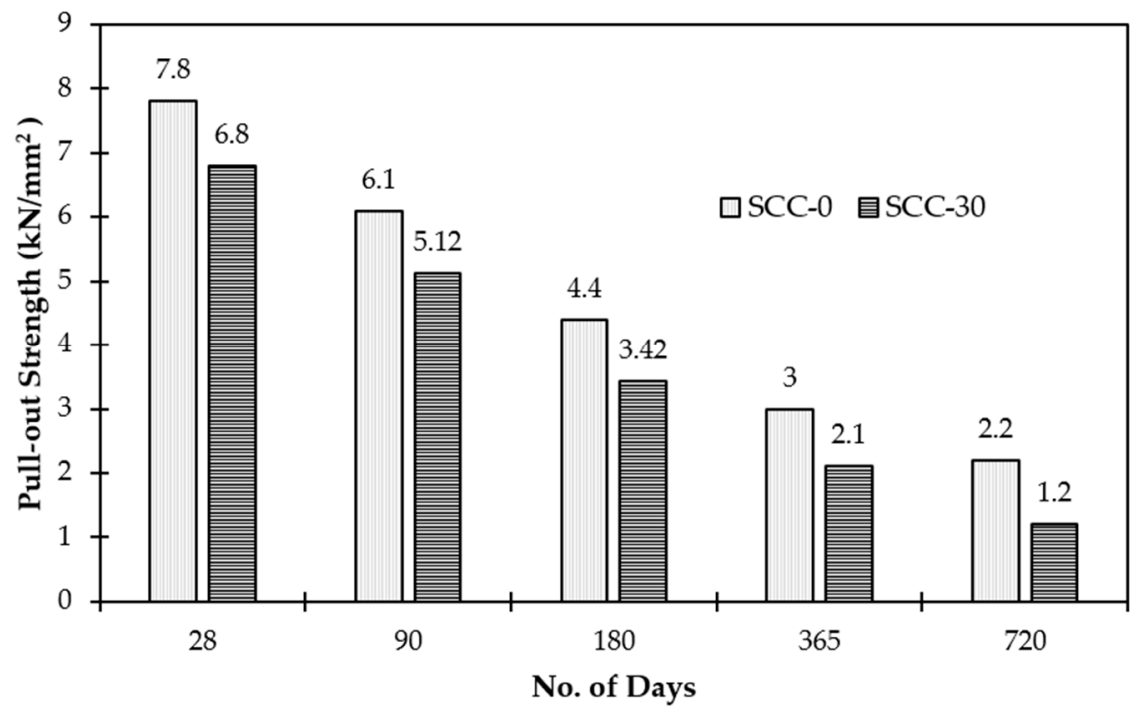

Figure 18. Pull-out strength test results of SCC samples at different ages. 


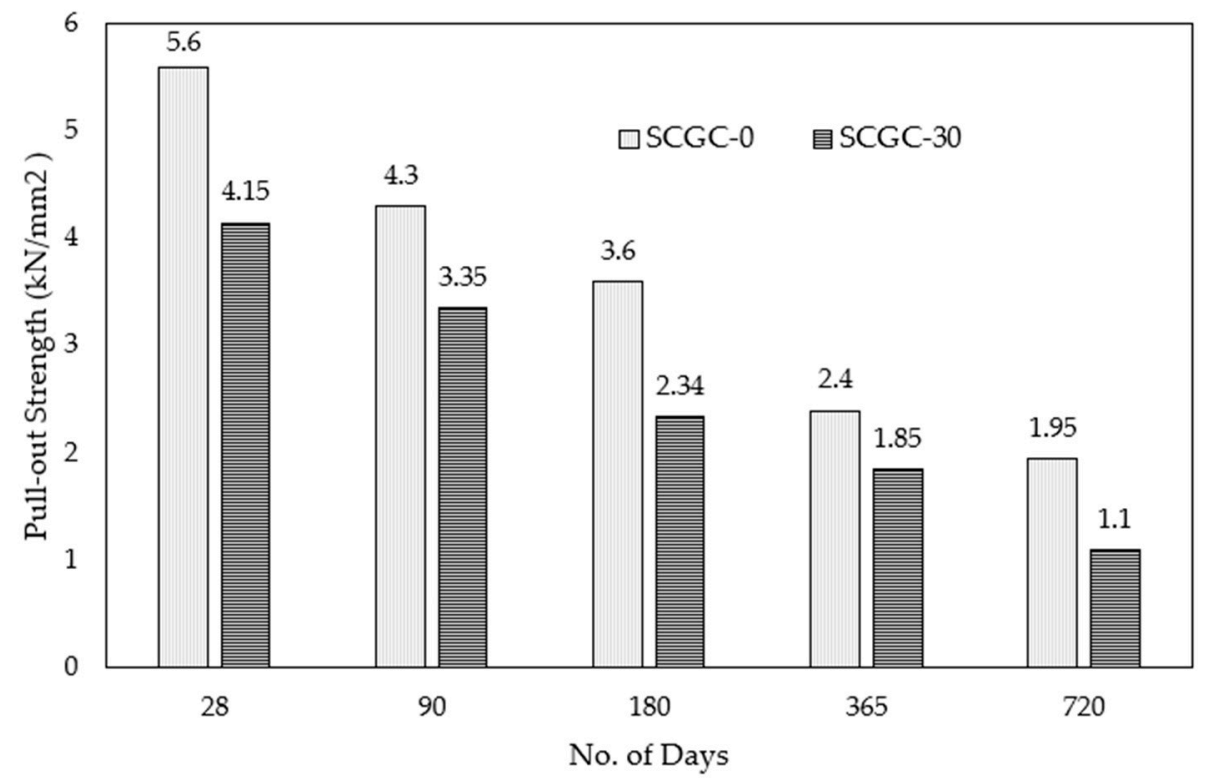

Figure 19. Pull-out strength results of SCGC samples at different ages.

From these results, it can be concluded that the bond strength for SCC is higher in the SCC-0 mix as compared to SCC-30 mix because it has a porous structure in the presence of recycled aggregate in SCC-30, as mentioned in [43]. Similar behaviour was observed in SCGC-0 and SCGC-30 mixes. Conversely, it can also be observed that SCC manifest more bond strength between concrete and steel bar as compared to SCGC mixes, i.e., SCGC-0and SCGC-30. The aforementioned results are due to the lower compressive strength, high water content and porous structure of SCGC as compared to SCC.

\section{Conclusions}

The use of RCA in place of NCA in and any type of concrete would be quite useful in reducing the rate of depletion of natural resources. In this research, sustainable concrete for the construction industry benefiting from the geopolymer technology and using RCA and fly ash in self-compacting geopolymer concrete (SCGC) was assessed for rheological, mechanical and durability performance. Based on the results from this experimental study of mechanical and durability properties of SCC and SCGC with and without RCA, it can be concluded that:

1. The replacement of NCA fraction up to $30 \%$ with RCA is satisfactory in terms of rheological properties as SCGC mix can be developed using RCA as it satisfied the requirements of EFNARC [25].

2. The use of $30 \%$ RCA as partial replacement of NCA reduced the compressive strength as much as $38.3 \%$ in SCC and $33.1 \%$ in SCGC, whereas the reduction in split tensile strength was $47.73 \%$ in SCC and 55\% in SCGC as compared to those mixes which contained $100 \%$ NCA.

3. SCC is found to be more resistant to penetration of water, carbon dioxide and chloride ions as compared to SCGC. SCC has higher bond strength, compression, and split tensile strength compared to SCGC.

4. Using 30\% RCA in SCC, the minimum to maximum reduction in water penetration depth, carbonation depth, half-cell potential difference, and pull-out strength was $5.71 \%$ to $22.22 \%, 11.69 \%$ to $47.73 \%, 44.23 \%$ to $64.29 \%$, and $12.82 \%$ to $45.45 \%$, respectively, as compared to those mixes which contained $100 \%$ NCA.

5. Using 30\% RCA in SCGC, the minimum to maximum reduction in water penetration depth, carbonation depth, half-cell potential difference, and pull-out strength was $15.71 \%$ to $20.64 \%, 10.53 \%$ to $47.1 \%, 28.73 \%$ to $34.49 \%, 22.1 \%$ to $43.59 \%$, respectively, as compared to those mixes which contained $100 \%$ NCA. 
Further investigation of durability tests exposed to the natural environment is recommended to validate the results of accelerated tests. This study focuses only on $30 \%$ replacement of natural coarse aggregates with recycled concrete aggregates; however, a detailed investigation on the effect of recycled concrete aggregate replacement percentage on the rheological, mechanical and durability-related properties of SCGC, along with the investigation for structural/infrastructural application, is also recommended. In addition, there can be a detailed investigation on the effect of various $\mathrm{Na}_{2} \mathrm{SiO}_{3} / \mathrm{NaOH}$ ratios and the molarity of $\mathrm{NaOH}$.

Author Contributions: Conceptualization, T.A.; data curation, W.M.; formal analysis, T.A., W.M.; funding acquisition, A.-u.-R.K.; investigation, W.M.; methodology, T.A.; supervision, A.-u.-R.K.; validation, W.M. and T.A.; writing-original draft, T.A.; writing-review \& editing, A.-u.-R.K. and W.M. All authors have read and agreed to the published version of the manuscript.

Funding: This research received no external funding.

Institutional Review Board Statement: Not applicable.

Informed Consent Statement: Not applicable.

Data Availability Statement: The data presented in this study are available on request from the corresponding author.

Acknowledgments: All those who supported the smooth conductance of experimental work.

Conflicts of Interest: The authors declare no conflict of interest.

\section{References}

1. Memon, F.A.; Nuruddin, F.M.; Shafiq, N. Compressive strength and workability characteristics of low-calcium fly ash-based self-compacting geopolymer concrete. Int. J. Civ. Environ. Struct. Constr. Archit. Eng. 2011, 5, 64-70.

2. Reddy, C.S.; Ratnasai, K.V.; Rathish Kumar, P.; Rajesh Kumar, P. Recycled Aggregate based Self Compacting Concrete (RASCC) for Structural applications. In Technical Paper Presented in R.N. Raikar Memorial International Conference; India Chapter of American Concrete Institute (ICACI): Mumbai, India, 2013.

3. Reddy, C.S.; Sai, K.R.; Kumar, P.R. Mechanical and durability properties of self compacting concrete with recycled concrete aggregates. Int. J. Sci. Eng. Res. 2013, 4, 255.

4. Reddy, C.S.; Sail, K.V.R.; Kumar, P.R.; Kuamr, G.R. Recycled Aggregate based Self Compacting Concrete (RASCC) for Structural applications. In Proceedings of the International Conference on Advances in Science and Technology of Concrete-Suru Shah Symposium, Mumbai, India, 20-21 December 2013.

5. Modani, P.O.; Mohitkar, V.M. Self-compacting concrete with recycled aggregate: A solution for sustainable development. Int. J. Civ. Struct. Eng. 2014, 4, 430-440.

6. Kapoor, K.; Singh, S.P.; Singh, B. Durability of self-compacting concrete made with Recycled Concrete Aggregates and mineral admixtures. Constr. Build. Mater. 2016, 128, 67-76. [CrossRef]

7. Ayub, T.; Khan, S.U.; Memon, F.A. Mechanical Characteristics of Hardened Concrete with Different Mineral Admixtures: A Review. Sci. World J. 2014, 2014, 875082. [CrossRef]

8. Tang, W.; Ryan, P.; Cui, H.Z.; Liao, W. Properties of Self-Compacting Concrete with Recycled Coarse Aggregate. Adv. Mater. Sci. Eng. 2016, 2016, 2761294. [CrossRef]

9. Satish, K.; Kumar, S.; Rai, B. Fly Ash Induced Self Compacting Concrete with Recycled Concrete Aggregate. Int. J. Mech. Solids 2017, 9, 151-168.

10. Naqi, A.; Jang, J.G. Recent Progress in Green Cement Technology Utilizing Low-Carbon Emission Fuels and Raw Materials: A Review. Sustainability 2019, 11, 537. [CrossRef]

11. Memon, F.A.; Nuruddin, M.F.; Khan, S.; Shafiq, N.; Ayub, T. Effect of sodium hydroxide concentration on fresh properties and compressive strength of self-compacting geopolymer concrete. J. Eng. Sci. Technol. 2013, 8, 44-56.

12. Cihangir, F.; Akyol, Y. Effect of Desliming of Tailings on the Fresh and Hardened Properties of Paste Backfill Made from Alkali-Activated Slag. Adv. Mater. Sci. Eng. 2020, 2020, 4536257. [CrossRef]

13. Farhan, N.A.; Sheikh, M.N.; Hadi, M.N. Investigation of engineering properties of normal and high strength fly ash based geopolymer and alkali-activated slag concrete compared to ordinary Portland cement concrete. Constr. Build. Mater. 2019, 196, 26-42. [CrossRef]

14. Galvin, B.; Lloyd, N. Fly ash based geopolymer concrete with recycled concrete aggregate. In Proceedings of the Concrete 2011 Conference, Perth, Australia, 12-14 October 2011. 
15. Naganur, I.K.; Ramesh, B.M.; Babu, V.; Nagaraj, V.K.; Arikeri, V.; Patil, N.R. A study on self-compacting geopolymer concrete with an alkaline activator ratio and different alkaline activator to cementitious binder ratios. Int. J. Eng. Appl. Sci. Technol. 2017, 5, 329-333.

16. Shaikh, F.U.A. Mechanical and durability properties of fly ash geopolymer concrete containing recycled coarse aggregates. Int. J. Sustain. Built Environ. 2016, 5, 277-287. [CrossRef]

17. Shaikh, F.U. Effects of alkali solutions on corrosion durability of geopolymer concrete. Adv. Concr. Constr. 2014, 2, 109-123. [CrossRef]

18. Olivia, M.; Nikraz, H. Strength and water penetrability of fly ash geopolymer concrete. J. Eng. Appl. Sci. 2011, 6, 70-78.

19. Sathia, R.; Ganesh Babu, K.; Santhanam, M. Durability study of low calcium fly ash geopolymer concrete. In Proceedings of the 3rd ACF International Conference-ACF/VCA, Ho Chi Minh City, Vietnam, 11-13 November 2008; pp. 1153-1159.

20. Le, H.-B.; Bui, Q.-B.; Tang, L. Geopolymer Recycled Aggregate Concrete: From Experiments to Empirical Models. Materials 2021, 14, 1180. [CrossRef] [PubMed]

21. Salihi, K.; Younis, K.H. Rheological Behaviour of Self-Compacting Geopolymer Concrete Containing Recycled Aggregates: Effect of $\mathrm{Na}_{2} \mathrm{SiO}_{3} / \mathrm{NaOH}$ and Molarity of $\mathrm{NaOH}$. Key Eng. Mater. 2021, 872, 79-84.

22. Khan, A.R.; Fareed, S.; Ayub, T. Mechanical Properties of Concrete made up from Recycled Coarse Aggregates. In Proceedings of the 14th Arab Structural Engineering Conference, ASEC14, Jordan, Egypt, 12-15 April 2018.

23. ASTM C114-18. Standard Test. Methods for Chemical Analysis of Hydraulic Cement; ASTM International: West Conshohocken, PA, USA, 2018.

24. Memon, F.A. Effect of Curing Conditions on Strength of Fly ash-based Self-Compacting Geopolymer Concrete. Int. J. Civ. Environ. Eng. 2011, 5, 342-345.

25. Self-Compacting Concrete European Project Group, The European Guidelines for Self-Compacting Concrete: Specification, Production and Use. 2005. Available online: http: / / citeseerx.ist.psu.edu/viewdoc/download?doi=10.1.1.121.6496\&rep=rep1 \&type $=$ pdf (accessed on 24 June 2021).

26. Nematollahi, B.; Sanjayan, J.; Shaikh, F.U.A. Tensile strain hardening behaviour of PVA fiber-reinforced engineered geopolymer composite. J. Mater. Civ. Eng. 2015, 27, 04015001. [CrossRef]

27. Zahid, M.; Shafiq, N.; Razak, S.N.A.; Tufail, R.F. Investigating the effects of $\mathrm{NaOH}$ molarity and the geometry of PVA fibers on the post-cracking and the fracture behaviour of engineered geopolymer composite. Constr. Build. Mater. 2020, 265, 120295. [CrossRef]

28. ASTM C39/C39M-14. Standard Test. Method for Compressive Strength of Cylindrical Concrete Specimens; ASTM International: West Conshohocken, PA, USA, 2014.

29. ASTM C617/C617M-15. Standard Practice for Capping Cylindrical Concrete Specimens; ASTM International: West Conshohocken, PA, USA, 2015.

30. Panda, K.C.; Bal, P.K. Properties of self compacting concrete using recycled coarse aggregate. Procedia Eng. 2013, 51, 159-164. [CrossRef]

31. Xie, J.; Wang, J.; Rao, R.; Wang, C.; Fang, C. Effects of combined usage of GGBS and fly ash on workability and mechanical properties of alkali activated geopolymer concrete with recycled aggregate. Compos. Part B Eng. 2019, 164, 179-190. [CrossRef]

32. ASTM C496/C496M-17. Standard Test. Method for Splitting Tensile Strength of Cylindrical Concrete Specimens; ASTM International: West Conshohocken, PA, USA, 2017.

33. Deutsches Institut fur Normung (DIN). Testing Concrete; Testing of Hardened Concrete (Specimens Prepared in Mould), in DIN 1048-5. 1991. Available online: https:/ / webstore.ansi.org/Standards/DIN/DIN10481991-1068705 (accessed on 24 June 2021).

34. European Committee for Standardisation (CEN). Measurement of the Carbonation Depth of Hardened Concrete, in CEN Report CR-12793. 1997. Available online: https:/ /standards.iteh.ai/catalog/standards / cen/ed564435-4396-49d2-8108-ec8f721f5da7 / cr-12793-1997 (accessed on 24 June 2021).

35. ASTM C876-15. Standard Test. Method for Corrosion Potentials of Uncoated Reinforcing Steel in Concrete; ASTM International: West Conshohocken, PA, USA, 2015.

36. ASTM C900-19. Standard Test. Method for Pullout Strength of Hardened Concrete; ASTM International: West Conshohocken, PA, USA, 2019.

37. Adnan, S.H.; Loon, L.Y.; Rahman, I.A.; Saman, H.M.; Soejoso, M.W. Water Permeability of Recycled Aggregate Concrete. In Proceedings of the Technology and Innovation for Sustainable Development Conference (TISD2008), Khon Kaen, Thailand, 28-29 January 2008.

38. Jones, M.R.; Dhir, R.K.; Newlands, M.D.; Abbas, A.M.O. A study of the CEN test method for measurement of the carbonation depth of hardened concrete. Mater. Struct. 2000, 33, 135-142. [CrossRef]

39. Dunster, A.M. Accelerated Carbonation Testing of Concrete; Building Research Establishment: Bracknell, UK, 2000.

40. Singh, N.; Singh, S.P. Carbonation and electrical resistance of self compacting concrete made with recycled concrete aggregates and metakaolin. Constr. Build. Mater. 2016, 121, 400-409. [CrossRef]

41. Shi, Z.; Shi, C.; Wan, S.; Li, N.; Zhang, Z. Effect of alkali dosage and silicate modulus on carbonation of alkali-activated slag mortars. Cem. Concr. Res. 2018, 113, 55-64. [CrossRef]

42. ASTM B117-19. Standard Practice for Operating Salt Spray (Fog) Apparatus; ASTM International: West Conshohocken, PA, USA, 2019.

43. Xiao, J. Recycled Aggregate Concrete; Springer: Berlin/Heidelberg, Germany, 2018. 